ROBERT J. SHILLER

Yale University

MAXIM BOYCKO

Institute of World Economy and International Relations

Russian Academy of Sciences

VLADIMIR KOROBOV

Kherson Pedagogical Institute

\title{
Hunting for Homo Sovieticus: Situational versus Attitudinal Factors in Economic Behavior
}

Many People are concerned that those who live in Eastern Europe and the former Soviet Union lack the attitudes-such as entrepreneurial spirit, initiative, leadership, motivation, and the willingness to take risks and assume responsibility-needed to function well in a market economy. So many people think that such attitudes are fundamentally lacking in the former Soviet bloc that it is popular to refer to people there as homo sovieticus, as though they were a different species of humankind. The idea seems to be that years of living in a communist system has produced a mind set—even a personality-different from that found in the

For help and suggestions, the authors wish to thank Hiroshi Amari, Gerwin Bell, Elizabeth Goldstein, Lawrence Katz, Walter Kraemer, William Mahota, Natasha Mamedova, Yuri Muravyev, William Nordhaus, Werner Ploberger, Thomas Richardson, Pat Ruzgis, Virginia Shiller, Andrei Shleifer, Toshiaki Watanabe, and participants in Cowles Foundation and NBER Behavioral Finance seminars. We also wish to thank the thousands of survey respondents for giving their time to our study. This research was supported by the U.S. National Science Foundation, the Institute of World Economy and International Relations of the Russian (Soviet) Academy of Sciences, and the Russell B. Sage Foundation. Part of the work for this article was done while Robert Shiller was a fellow of the John Simon Guggenheim Memorial Foundation and while Maxim Boycko was supported by the Ford Foundation. 
advanced capitalist countries, and while these characteristics probably are not immutable, they may not change dramatically for generations. If this homo sovieticus theory is true, then serious problems will arise in the formerly communist countries as they make the transition to successful market economies.

Why do so many people think that people in ex-communist countries and advanced capitalist countries have such different attitudes? Certainly people who travel between countries report differences in behavior. They may trade stories, for example, about how much more helpful some waiters or salespeople were in capitalist countries. Differences in economic behavior between countries certainly exist. But to what extent are different behavior patterns due to deeply ingrained differences in attitudes?

For example, people are observed to hoard more goods in their homes in ex-communist countries. Should we assume that this hoarding behavior is due to acquisitive or selfish attitudes? People are observed to spend more time standing in line in ex-communist countries. Should we assume that people queue because of their gregarious or obedient attitudes? Certainly, better explanations exist for such behavior-explanations in terms of the economic situations that people in ex-communist countries face.

Our objective is to sort out some reasons that differences in economic behavior occur between the ex-communist and advanced capitalist economies. We want to distinguish factors that are attitudinal from factors that are situational. Attitudinal factors relate to psychological traits, personality, and culture. ${ }^{1}$ Situational factors relate to people's perceptions of their economic situation. Relevant factors include the institutions that affect them, their economic expectations, and their expectations about how other people will react to their own actions. In economists' terms, attitudinal factors are matters of taste and preference, while situational factors are the perceived constraints under which people operate.

The relative role of attitudinal and situational influences in behavior is of crucial importance in determining the optimal speed for pro-market economic reform to proceed in ex-communist countries. Situational influences may change quickly. If such situational influences predomi-

1. We use the term "attitudinal" more broadly than most social scientists do. 
nate, as policy regimes change, we may hope for quick progress; thus reforms should proceed quickly. On the other hand, if attitudinal factors predominate, then policy makers in ex-communist countries might be advised to be cautious about the transition to a market economy. The parable of Moses could well apply: Moses kept the Jews wandering in the wilderness and out of the promised land until they had rid themselves of destructive attitudes when the last of their generation had died.

This research is a continuation of earlier work on differences between popular attitudes in the former Soviet Union and the United States. In earlier work, we conducted identical telephone interviews in Moscow and New York, focusing primarily on respondents' attitudes toward and understanding of markets, their views on such features as the fairness of price changes, and the importance they placed on income equality. ${ }^{2} \mathrm{We}$ first used a few questions presented in this paper in interviews for our 1991 work. This paper expands the focus of our earlier work to economic behavior, rather than opinions about markets, and greatly expands the populations of people studied.

Our method is to undertake structured interviews of people in the excommunist countries and their counterparts in advanced capitalist countries and compare answers. To allow intercountry comparisons, we posed identical questions in each country (to the limits possible with translation). We studied three ex-communist countries-Russia, Ukraine, and eastern Germany-and three advanced capitalist economies-the United States, Japan, and western Germany. ${ }^{3}$ We conducted 2,670 interviews over the past two years, both in person and by telephone, in 21 separate sets of interviews in six countries. (We held more interviews in Russia, Ukraine, and the United States than in the other countries.)

Using these interviews, we can employ several ways to distinguish whether people behave differently in different countries because of the different attitudes they hold or the different situations they face. The first method probes situations. We can question subjects in ex-communist countries directly about important perceptions of the economic situation they face. When it makes sense to do so, we can compare their an-

2. Shiller, Boycko, and Korobov (1991).

3. We refer to eastern Germany and western Germany as separate countries because of their recent separation, even though unification occurred in October, 1990, a year before we conducted our interviews. 
swers with answers to the same questions given by respondents in advanced capitalist countries. We can probe only those perceptions that might be relevant when people choose whether to engage in certain behavior, such as using initiative, taking risks, or working hard. For example, we can ask whether they believe that it is worth their while to try to convince their bosses to put a good idea into practice, or whether respondents think that the government someday will expropriate the benefits of their hard work. From their responses, we can gain some sense of the likelihood that situational factors explain behavior.

The second method probes attitudes. We can question subjects in excommunist and advanced capitalist countries about how they would behave in hypothetical situations and compare answers. These questions fully spell out the situation and are the same in all countries. Thus differences in answers can only be attitudinal; we hold constant the situation and allow only attitudes to vary.

These two methods are the main techniques in our arsenal. We also have one more method that is of some value. This technique was made possible for us by an odd quirk of fate: a coup d'état erupted in August 1991 in the midst of our interviews in Ukraine. This coup resulted in President Mikhail Gorbachev's arrest and return; shortly thereafter, the Baltic states were freed and Soviet Union was completely dissolved. We can compare answers to the same questions before the attempted coup and four months later to see how much the answers were changed by the coup attempt and subsequent events. Presumably, deeply ingrained attitudes will not change in such a short interval; thus any changes in behavior must be situational. In contrast to our second method, in this third technique, we hold constant the attitudes and allow only situations to vary. Unfortunately, we did not take full advantage of this research opportunity because we did not know it was coming.

We need to offer some warnings about this research effort. Certainly, we are attempting something difficult-to sort out reasons for people's behavior. Interpreting results requires some judgment. Any of our conclusions could be easily criticized. One reason that economists have displayed a comparative lack of interest in studying the psychological or cultural issues that we have considered may be that it is hard to rigorously establish the importance of such attitudes. Those few intrepid scholars who have tried were roundly criticized, and probably many of them found it more fruitful to look for other avenues of research. 
We have presented many results in this paper, even results that are puzzling or that do not seem to discriminate sharply between our opposing theories. Our methods are not so precise that we can sort through our results and know which ones will be useful to readers trying to make judgments about human behavior. The weight of the evidence from many different questions concerns us more than the results from any one question. We do not want to "data mine"- that is, to present only results that seem to support one view. Thus, between this and our earlier paper, we reported more than 90 percent of the attitudinal and situational questions we asked (not including background questions, such as those about age or education). Sometimes we ask very similar questions or seemingly the same question in different ways. This method is justified to confirm our understanding because survey results can be heavily influenced by the way questions are worded.

Our methods are rather exploratory, so we have not relied heavily upon statistical tests; we are not always sure exactly what hypotheses we want to test. To our minds, so many issues of interpretation arise with the results that we do not have space to discuss them all; we must leave them largely to the reader's own judgment. One major issue of interpretation is whether certain questions really are probing situations or attitudes; we admit that ambiguity sometimes exists about how questions should be classified. A few of our questions might better be described as general questions about economic behavior that may only offer clues about situations or attitudes. Finally, we must apologize to the readers for the seemingly erratic choices of which countries to use for which questions. The exploratory research that we did over time in various countries had a logic that may escape readers of this final report.

In the next section, we present a literature review and discuss our survey methods. We then discuss our results in an effort to sort out situational and attitudinal factors in economic behavior. We try to sort these out first in terms of everyday life, on such matters as dealing with authorities. Then we examine labor market behavior and entrepreneurial, investment, and saving behavior. Next, we look at pre- and post-coup responses. We then examine the statistical significance of differences several ways: between ex-communist and advanced capitalist countries; between eastern and western Germany; and between Russia and Ukraine. Then we discuss some of the implications of our results for two problems in the ex-communist countries: the prevalence of short-term 
outlook and behavior and a lack of commitment to current firms. We analyze the distinction between situation and attitude in terms of the weight of all of our results. Finally, we present our conclusions.

\section{Previous Comparisons of Communist and Capitalist Countries}

It is difficult to summarize the vast literature on attitudinal differences across countries that might account for differences in economic success. Psychologists, sociologists, and anthropologists have hundreds of ideas about research that might be relevant.

Scholarly discussion of the role of attitudes in economic development dates back at least to Max Weber, who in 1920 made a widely cited claim that a "protestant ethic" has fostered economic progress in the West. ${ }^{4}$ Nonetheless, the number of tangible, concrete studies that might give evidence of the importance of cultural factors in economic development seems surprisingly small, given this topic's enormous potential importance.

The promise-and doubts-surrounding this topic are exemplified by the journal Economic Development and Cultural Change, which was founded by Bert Hoselitz in 1952 to study development with a cultural perspective. In the first article of the first issue, Hoselitz expressed some interest in economists' theories relating development to such factors as new techniques or new capital instruments. However, he then asserted that "it is doubtful whether the transformation of a society can be explained in such a simple fashion, and there is doubt that the obstinacy with which people hold to traditional values, even in the face of rapidly changing technology and economic organization, may impose obstacles of formidable proportions." 5

Despite his urging, the journal never published many papers that concerned study of such values. Instead, recent issues seem to be devoted to such matters as measurements of income distribution, the determinants of fertility, the effects of foreign direct investment, and empirical models of public choice. As we mentioned, the lack of interest in attitudes as determinants of development may be due to the difficulty in

4. See Weber (1920).

5. Hoselitz (1952, pp. 8-9). 
making solid progress in research. Fortunately, however, some scholars have tried to make some progress in understanding attitude differences in the communist countries.

One attitudinal factor in particular-achievement motivation-has been the subject of much attention as possibly explaining differences in economic performance across countries. Careful cross-country comparisons in the achievement motivation scale have been developed by David McClelland and his colleagues. ${ }^{6}$ One of their methods for evaluating their subjects' achievement orientation is to show them pictures of people in various activities and ask subjects to make up stories about the pictures. McClelland and his colleagues counted the frequency of references to personal achievement in the stories and coded the results. Another of their methods is to find a random sample of published popular literature and then code the references to achievement in this literature. Both these methods yielded $n$-achievement indexes for individual countries at a point in time. McClelland and his colleagues reported that on some occasions, the $n$-achievement content of popular literature increased before times of rapid economic growth and decreased when growth slackened. Moreover, countries whose children's literature scored high on $n$ achievement tended to grow more than other countries in the succeeding 25 years. Individual college students who attained high $n$-achievement scores tended more often to become entrepreneurs.

According to McClelland, studies show that people with high $n$ achievement scores tend to take moderate or calculated risks, and take on tasks of moderate difficulty that can be realistically completed. They are not risk-lovers; they tend to take risks that can be moderated by their own skills and for which they would "gain the most achievement satisfaction from succeeding." ${ }^{, 7}$ McClelland interprets high $n$-achievement people as those who have the entrepreneurial spirit that would foster economic growth.

However, the correlation McClelland found across countries between $n$-achievement scores and economic growth was actually rather modest. Notably, economically successful Japan scored quite low on $n$ achievement: McClelland's score for Japan was 1.29, compared to an average score of 2.00 for 33 countries. The U.S. score of 2.24 was mod-

6. See McClelland (1961).

7. McClelland (1961, p. 213). 
erately above the average. The Soviet Union, with a score of 2.10, also ranked a little above average. ${ }^{8}$ Perhaps McClelland's scoring method is not finely focused enough on the attitudes necessary for economic growth, and too many other purely economic factors impinge on growth rates.

Another potential problem surrounds McClelland's method: differences in $n$-achievement scores across countries may reflect different situations, rather than different attitudes. Differences in such scores may reflect different expectations that an effort to achieve will succeed, as well as different motivations to achieve. When shown a picture, people in one culture may respond with images of achievement because they have learned to expect to see such achievement. That people in other cultures fail to think of achievement images when shown a particular picture may in fact be merely another reflection of the economic situation in these economies. McClelland and his colleagues were repeatedly criticized for not giving this possibility proper consideration. ${ }^{9}$ For example, one study found that men with high $n$ achievement who worked in firms that offered no possibility of advancement had lower $n$-achievement scores after three years. ${ }^{10}$ Nonetheless, we do not wish to dismiss McClelland's provocative work for these reasons $;{ }^{11}$ rather, we want to sort out the situational factors so we can learn more about some of the same attitudinal parameters that he studied.

Another attitudinal dimension, emphasized by Geert Hofstede, is uncertainty avoidance. His Uncertainty Avoidance Index (UAI) is intended to measure to what extent people are inhibited by the anxieties created by uncertainties. The index is based on answers to three questions. First, the index is affected positively by rule avoidance: agreement with the statement "company rules should not be broken-even when the employee thinks it is in the company's best interests." Second, the index is affected positively by employment stability: employees' statement that they intend to continue with the company for more than five years. Third, the index is affected negatively by reports of stress,

8. See McClelland (1961, appendix table II, pp. 461-63).

9. See, for example, Eisenstadt (1963). For a response, see McClelland and Winter (1969).

10. See Andrews (1967).

11. A number of studies have found that achievement motivation training programs improve economic success in small businesses. See Miron and McClelland (1979). 
measured by mean answers to the question "how often do you feel nervous or tense at work?" 12 Hofstede computed values for this index for 40 countries; the mean index was 64 and the range for the 40 countries was 8 to 112 . His UAI did not show any consistent correlation with McClelland's $n$ achievement.

The only communist country in Hofstede's sample-Yugoslaviarated fairly highly on uncertainty avoidance, receiving a UAI of 88 . In personal correspondence to us, Hofstede indicated that he now has developed uncertainty avoidance indexes for a number of ex-communist countries. Russia received a moderately high UAI of 75 ; eastern and western Germany had the same index value of $65 .{ }^{13}$

Hofstede found little correlation across countries between his index and economic success. Japan received one of the highest scores in uncertainty avoidance $(\mathrm{UAI}=92)$, while Sweden received one of the lowest $(\mathrm{UAI}=29) .^{14}$

Hofstede was more successful in finding an index that correlates with economic success with another measure, the Power Distance Index (PDI). This index is based on mean answers to three questions: (a) "nonmanagerial employees' perception that employees are afraid to disagree with their managers"; (b) "subordinates' perception that their boss tends to take decisions in an autocratic or persuasive/paternalistic way"; and (c) "subordinates' preference for anything but a consultative style of decisionmaking in their boss." 15 The mean of the index was 51, with scores for the 40 countries ranging from 11 to $94 .{ }^{16} \mathrm{High}$ PDI countries, where management is more autocratic, showed a distinct tendency to be less developed. We are inclined to categorize the Power Distance Index as an index of situation, rather than attitude (although this categorization is not unambiguous).

The one communist country in Hofstede's original sample-Yugoslavia-ranked fairly high on power distance, with a score of 76 . With his newer sample of Soviet export managers, the PDI was 93, virtually at the extreme high end of power distance. This suggests major problems

12. Hofstede (1980, p. 164).

13. Hofstede reports that his sample of 55 export managers in Russia is "neither homogeneous nor well matched with my samples in [the 1980 work] Culture's Consequences."

14. Hofstede (1980, p. 165).

15. Hofstede (1980, p. 103).

16. Hofstede (1980, p. 104). 
for the former Soviet countries. Eastern and western Germany had the same low PDI value of 35 .

Another intercountry psychological or personality difference-difference in individualism - has broad implications for economic behavior. The literature comparing patterns of individualism across countries has been extensive, dating back as far as the 1830s, to Alexis De Tocqueville's classic work, which compared Americans with Europeans and found Americans to be more individualistic. ${ }^{17}$ Many different dimensions to individuality exist and there has been a corresponding diversity of studies. Quantitative international comparisons have examined the degree of homogeneity of societies, as well as synchronization, the degree of personalization, and the difficulty of social interactions. Many intercultural studies have compared various kinds of child-rearing practices and examined the resultant lessons about cooperation, assertiveness, and mobility. Intercultural studies have investigated social perceptions, including the perceived desirability of such traits as conscientiousness and agreeableness. Few of these studies examined communist countries, and few specifically tried to correlate their factors with economic success.

Fritz Gaenslen compared certain concepts of individualism in China, Japan, Soviet Russia, and the United States by locating 1,000 interpersonal disagreements drawn from contemporary Chinese, Japanese, Soviet Russian, and American fiction. He coded various factors evident in these fictional disagreements and inferred differences in individualistic tendencies across these countries: he concluded that the United States was more individualistic than the other three nations. For example, he found that the more prominent a normative argument (along the lines of "do it this way because it is proper") the more likely the superior is to vin in China, Japan, and Soviet Russia, but not in the United States. His study reached no striking conclusions about the likely impact these differences in individualism would have on economic development, concluding only that:

First, Chinese, Japanese and Russian subordinates, more so than American ones, may be expected to desire to push responsibility onto those above them. Second, they may be expected, more than their American

17. See Triandis (1989) for a survey of literature on intercultural studies of individualism. 
counterparts, to desire to present superiors with unanimous recommendations rather than confronting them directly as individuals. Finally, they may be more reluctant than American subordinates to participate in decisionmaking in the first place. ${ }^{18}$

Perhaps Gaenslen's method comes closest to ours. Looking at disagreements from fiction may abstract from the economic situation and thereby inform us of attitudinal traits. However, we think that there are better means of holding situations constant across countries.

Intercountry studies have compared how people in various countries allocate time. F. Thomas Juster and Frank Stafford compared the total hours per week that men and women worked (including time spent commuting and doing housework) in Finland, Hungary, Japan, the Soviet Union (represented by Pskov only), Sweden, and the United States. ${ }^{19}$ Among men, the total was highest in the Soviet Union, where men worked 65.7 hours. Next highest was Hungary; there, men worked 63.7 hours per week. U.S. men worked 57.8 hours per week. The total was lowest-55.5 hours per week-among Japanese men (who ranked high on hours spent in market work, including commuting, but who did very little housework). Among women, Hungary ranked highest: there, women worked 68.9 hours per week; Soviet women ranked second highest, with 66.3 hours per week. Japanese women worked 55.6 hours per week. U.S. women came in last with 54.4 hours per week. The total number of hours per week people spent watching television was highest in Japan for both men and women: men watched 17.3 hours and women watched 21.4 hours. Those figures compared with weekly totals of 14.5 hours for Soviet men, 11.2 hours for Soviet women, 12.7 hours for U.S. men, and 11.5 hours for U.S. women. ${ }^{20}$ These statistics contain no inference that people in ex-communist countries are lazy. However, as with all the measures described above, we cannot say whether any differences observed across countries are caused by differences in fundamental attitudes or differences in economic situations. We cannot be sure

18. Gaenslen (1986, p. 97).

19. Juster and Stafford (1991).

20. Juster and Stafford (1991, table 1, p. 475). Blanchflower and Oswald (1989) compared labor force participation rates in Austria, Britain, Hungary, Italy, Switzerland, the United States, and West Germany, using International Social Survey Program data. The one Soviet bloc country in the comparison-Hungary-yielded unexceptional results: its participation rate was the median for the seven countries. 
whether Japanese men and women would not work much more and watch television much less if they were transferred to a Soviet-style economic environment.

\section{Questionnaire Design and Survey Methods}

Our first surveys were undertaken in Moscow and the United States, as part of the work reported in our 1991 paper. None of the respondents was told that they were involved in an international comparison study. Instead, interviewers identified themselves as belonging to a domestic research organization; they were native speakers of the language in which they conducted the interview.

To keep the length of the interview within reasonable bounds, and so that respondents would feel that they would have time to answer each question thoughtfully, the questions were arranged into short questionnaires. (We assigned letters of the alphabet to each questionnaire and designated each question by a letter and number, such as A1. These designations appear before each question discussed in this paper.) Most of our surveys involved several such questionnaires. Respondents to each questionnaire were told that the interview would not take more than ten minutes.

Table 1 summarizes the methods we used to administer our various questionnaires, as well as the sample size, dates, and locales of our various surveys. Questionnaires A, B, and C were administered by telephone in Moscow from May 5-23, 1990, to randomly sampled individuals 18 years of age or older: we received 130, 137, and 124 responses, respectively. In this and all of our surveys in the former Soviet republics, we personally supervised the interviews, hiring the interviewers and managing them ourselves. In the United States, exact translations of questionnaires A, B, and C were given from May 21 to May 23, 1990, to a random sample of individuals aged 18 years and older from the New York City Consolidated Metropolitan Statistical Area. Key Communications, Inc. administered the three questionnaires; we received 120, 120 , and 121 responses, respectively. We reported many of the results from these surveys in our 1991 paper.

In Tokyo, the Japan Market Research Bureau duplicated some of the 
Table 1. Summary of Surveys

\begin{tabular}{|c|c|c|c|c|c|}
\hline Country & Locale & $\begin{array}{l}\text { Month } \\
\text { and year }\end{array}$ & Method & Questionnaire $^{a}$ & $\begin{array}{c}\text { Sample } \\
\text { size }\end{array}$ \\
\hline Russia & Moscow & May 1990 & $\begin{array}{l}\text { phone } \\
\text { phone } \\
\text { phone }\end{array}$ & $\begin{array}{l}\text { A } \\
\text { B } \\
\text { C }\end{array}$ & $\begin{array}{l}130 \\
137 \\
124\end{array}$ \\
\hline United States & New York & May 1990 & $\begin{array}{l}\text { phone } \\
\text { phone } \\
\text { phone }\end{array}$ & $\begin{array}{l}\text { A } \\
\text { B } \\
\text { C }\end{array}$ & $\begin{array}{l}120 \\
120 \\
121\end{array}$ \\
\hline Japan & Tokyo & February 1991 & phone & $\mathbf{J}$ & 126 \\
\hline $\begin{array}{l}\text { Ukraine } \\
\text { (pre-coup) }\end{array}$ & Kherson & August 1991 & $\begin{array}{l}\text { door-to-door } \\
\text { door-to-door } \\
\text { door-to-door } \\
\text { phone }\end{array}$ & $\begin{array}{l}\mathrm{D} \\
\mathrm{K} \\
\mathrm{M} \\
\mathrm{H}\end{array}$ & $\begin{array}{l}121 \\
123 \\
118 \\
130\end{array}$ \\
\hline $\begin{array}{l}\text { Ukraine } \\
\quad \text { (post-coup) }\end{array}$ & Kherson & December 1991 & $\begin{array}{l}\text { door-to-door } \\
\text { door-to-door }\end{array}$ & $\begin{array}{l}\mathrm{D} \\
\mathrm{PC}\end{array}$ & $\begin{array}{l}131 \\
130\end{array}$ \\
\hline United States & $\ldots$ & September 1990 & $\begin{array}{l}\text { phone } \\
\text { phone }\end{array}$ & $\begin{array}{l}\mathrm{H} \\
\mathrm{U}\end{array}$ & $\begin{array}{l}123 \\
127\end{array}$ \\
\hline Russia & Omsk & February 1992 & $\begin{array}{l}\text { door-to-door } \\
\text { door-to-door } \\
\text { door-to-door } \\
\text { phone }\end{array}$ & $\begin{array}{l}\mathrm{D} \\
\mathrm{K} \\
\mathrm{M} \\
\mathrm{H}\end{array}$ & $\begin{array}{l}130 \\
130 \\
130 \\
130\end{array}$ \\
\hline Eastern Germany & $\cdots$ & December 1991 & phone & G & 132 \\
\hline Western Germany & . . & December 1991 & phone & G & 137 \\
\hline
\end{tabular}

Source: Surveys conducted by the authors. See text for more information.

a. Questionnaires J, PC, U, and G contain questions from other questionnaires.

same questions with 126 respondents. ${ }^{21}$ A selection of questions from questionnaires $\mathrm{A}, \mathrm{B}$, and $\mathrm{C}$ was used; questions were not modified, except for translation into Japanese. A single questionnaire interview was conducted by telephone from February 1 to February 5, 1991, to a random sample of respondents 18 years of age and older.

Two surveys were then undertaken in Kherson, in south-central Ukraine, about 300 miles from the Russian border. Kherson is a port city on the Black Sea at the mouth of the Dniepr River. Its population was 355,000 , as of 1989 . The city specializes in shipbuilding and supports other industries, including oil refining, glassworking, and canning of

21. Elizabeth Goldstein directed our Japan survey. 
produce. The surrounding countryside is a once-arid plain that now produces grains, fruits, and vegetables. We asked our Kherson respondents "What language do you consider your native language?" Fifty-four percent of the 472 respondents said Russian; 40 percent said Ukrainian; and 6 percent said another language. Interviewers conducted the surveys in Russian.

Although Kherson may be described as substantially "Russified," a distinct regional culture exists that, we think, differs from the culture of Moscow or Siberia more than the U.S. Midwest does from the East. The first survey (Ukraine/pre-coup) was undertaken from August 2 to August 19, 1991, and was underway until the day before the attempted coup d'état that led to President Gorbachev's arrest and triggered the final dissolution of the Communist party and the Soviet Union. Although we had planned to obtain a somewhat larger sample, the survey was terminated on that day. Thus, all answers are pre-coup. Questionnaires D, K, and $\mathrm{M}$ were conducted on a door-to-door basis and yielded 121, 123, and 118 respondents, respectively. Questionnaire $\mathrm{H}$ was conducted by telephone; 130 people responded.

The second survey (Ukraine/post-coup) was administered door-todoor in Kherson several months later, from November 27 to December 18, 1991. Questionnaire D was used again without change, but to a new random sample: 131 people responded. In addition, a new questionnaire, PC, was administered that included some new questions, as well as questions from the other questionnaires used in the previous survey in Ukraine. Some 130 people responded.

The second U.S. survey, conducted from September 3 to September 9, 1991, by Key Communications, Inc., questioned employed individuals aged 18 and older from the continental United States, using questionnaire $\mathrm{H}$, as well as questionnaire $\mathrm{U}$, which contained some questions from the other questionnaires. We received 123 and 127 responses, respectively. Respondents were chosen through a randomdigit telephone sample from the continental United States provided by Survey-Sampling, Inc.

In Germany, surveys were undertaken by telephone from December 17 to December 20, 1991, using a random-digit dialing method that assured even coverage in both eastern and western Germany. Respondents were employed workers aged 18 and older; we received 132 re- 
sponses from eastern Germany and 137 from western Germany. A screening question eliminated respondents who had not lived most of their lives in the part of Germany they currently lived, to eliminate those who had moved since unification. The survey was carried out by FORSA, Gesellschaft für Sozialforschung und statistische Analysen, Dortmund. We used questionnaire $\mathrm{G}$, which contained a selection from the Ukraine questionnaires and a few additions.

For our second Russian survey, conducted from January 31 to February 6, 1992, we chose the western Siberian city of Omsk. The city, with a population of 1,167,000 (as of 1991), lies at the confluence of the Irtysh and Om rivers, some 1,400 miles east of Moscow, across the Ural mountains; it is 1,800 miles from Kherson. We chose this rather distant location in response to criticisms that our first survey, done in Moscow, was not representative of the Russian people. Omsk is a major port and produces agricultural machinery and railway equipment. It also has oil refineries, grain mills, textile plants, and a university. All four Ukraine questionnaires were administered door-to-door, except for questionnaire $\mathrm{H}$, which was conducted by telephone. Only a few minor modifications were made in the questions. We sampled employed individuals 18 years of age and older and received 130 responses to each of questionnaires $\mathrm{D}, \mathrm{H}, \mathrm{K}$, and $\mathrm{M} .^{22}$

In preparing the questionnaires, we were confronted by a serious difficulty: the questionnaires had to be presented in four languages-English, Russian, German, and Japanese. (The Ukrainian questionnaire was conducted in Russian because nearly everyone in Kherson speaks Russian.) Of necessity, we are comparing answers to questions written in different languages (except for the comparison between eastern and western Germany).

In preparing our translations, we adopted methods used by cultural anthropologists. As much as possible, we attempted to produce what those anthropologists call "decentered" translations, which contain "both loyalty of meaning and equal familiarity and colloquialness in each language." ${ }^{23}$ To prepare such translations, a questionnaire is not drawn up in one language and then merely translated into other languages. That

22. Yuri Muravyev directed our Omsk surveys.

23. Werner and Campbell (1970, p. 398). 
would result in a "uni-centered" set of translations that would give one language priority and could present terms that, while familiar in the first language, could appear exotic or unnatural in another. To produce decentered translations, one uses an iterative procedure-"back translation"-devised by anthropologists, sociologists, and social psychologists. ${ }^{24}$ Because much of our research was undertaken sequentially, we could not always employ such decentered translation. We used a backtranslation program for our first United States-Russia (New York-Moscow) comparisons and then again for our United States-Ukraine (continental United States-Kherson) comparisons. The questionnaire was first translated from English into Russian. Then, with attention to the difficulties of translation, the English version was modified and the Russian version was modified yet again. Independent bilingual readers checked all translations.

In the United States, Germany, and Moscow, all surveys were administered by telephone. A significant potential problem exists in comparing eastern and western Germany because eastern Germany has far fewer telephones: only 17 percent of eastern German households had telephones in $1989 .{ }^{25}$ In the former Soviet republics, the dearth of telephones is less severe, but still an issue. In Moscow in 1988, 89 percent of apartments had telephones. ${ }^{26}$ Probably about half of all apartments in Kherson and Omsk have telephones. ${ }^{27}$ Our Ukraine (Kherson) and Russia (Omsk) surveys avoided the telephone problem somewhat by conducting door-to-door surveys for all questionnaires, except $\mathrm{H}$.

To get a random sample in the United States and western and eastern Germany, we used random-digit dialing methods conducted by professional sampling organizations. In Ukraine and Russia, we used randomdigit dialing for metropolitan Omsk, Kherson, and Moscow and random sampling of blocks for the door-to-door surveys.

Sample size in our results is relatively constant-about 100 respondents. Thus the standard error of a sample proportion is about 5 percentage points if the sample proportion is one half; 4 percentage points if the

24. Triandis (1972).

25. DDR in Zahlen 1990, Statistisches Bundesamt, Wiesbaden.

26. Moskva v Tsifrakh, 1989.

27. There are 13.8 telephones per 100 citizens in Kherson. 
sample proportion is 25 percent or 75 percent; and 3 percentage points if the sample proportion is 10 percent or 90 percent.

\section{Survey Results about Everyday Behavior}

Our first set of questions aimed at finding out more about situational and attitudinal influences on everyday life.

\section{Situational Influences on Everyday Behavior}

We first asked respondents about situations everyone faces from time to time in formal situations, dealing with those in authority either directly or in arms-length transactions. As with all our questions, we devised these queries in light of our own personal experience. We had the impression that institutions in the former Soviet bloc do not respond well to individuals' efforts to be helpful, and that when people interact in formal situations in these countries, they may encounter unsympathetic and even hostile behavior.

Let us first mention an extremely important situational difference between the ex-communist and advanced capitalist countries. ${ }^{28}$ More people in the ex-communist countries report that they do not believe that incentives exist for people to take any initiative to do quality work. We devised the following question to probe differences in situations across countries:

D3. Suppose you had an idea how to improve the workings of your company or organization and you are absolutely sure that the idea is good. Do you think it is worthwhile for you personally, from the point of view of your own interests, to try to persuade your bosses to put this idea into practice?

28. In this, as in all questions, we display results from the ex-communist countries first; then, after a blank line, we present responses from advanced capitalist countries. In this and in all questions, survey size is the number of respondents that answered this question. Although international differences occur in the proportion of no answers, we do not attach much significance to these differences; they may reflect differences in surveyors' efforts to press for an answer. 
Responses in percent

$\begin{array}{lccc} & \text { Yes } & \text { No } & \begin{array}{c}\text { Survey } \\ \text { size }\end{array} \\ \text { Ukraine (pre-coup) } & 53 & 47 & 102 \\ \text { Ukraine (post-coup) } & 63 & 37 & 105 \\ \text { Russia (Omsk) } & 60 & 40 & 110 \\ \text { United States } & 90 & 10 & 126\end{array}$

A clear difference emerges when responses in ex-communist countries are compared with answers from the United States. This indicates that people in the ex-communist countries face different constraints and different incentives (if we can generalize from the answer to this question.) The difference in incentives would tend to cause people to behave less helpfully in formal situations. The difference in answers does not indicate any differences in respondents' attitudes: it does not suggest any lack of willingness to persuade one's boss to put the idea into practice. To argue that the difference in answers is actually caused by a difference in respondents' attitudes, one would have to argue that people let their emotions dominate their answers or that respondents misinterpreted the question. It is not our impression that respondents had any trouble understanding and answering this question, which was based on simple facts.

We sought further evidence of authorities' general unresponsiveness:

H5. The streets are cleaned badly on your block. Suppose that you and twenty of your neighbors are ready to sign a petition, demanding an improvement in the situation. Do you think this will lead to any real results?

Responses in percent

$\begin{array}{lccc} & \text { Yes } & \text { No } & \begin{array}{c}\text { Survey } \\ \text { size }\end{array} \\ \text { Ukraine (pre-coup) } & 27 & 73 & 116 \\ \text { Russia (Omsk) } & 19 & 81 & 124 \\ \text { Eastern Germany } & 34 & 66 & 122 \\ & & & \\ \text { United States } & 58 & 42 & 123 \\ \text { Western Germany } & 61 & 39 & 122\end{array}$

H11. Suppose that the relations between your child and his teacher are not developing very well. Do you think it is worthwhile to go to the principal and ask him to transfer your child to another class? Or is it more likely that he will refuse to do so? 
Responses in percent

$\begin{array}{lccc} & \begin{array}{c}\text { Worthwhile } \\ \text { to ask }\end{array} & \begin{array}{c}\text { Highly likely } \\ \text { to refuse }\end{array} & \begin{array}{c}\text { Survey } \\ \text { size }\end{array} \\ \text { Ukraine (pre-coup) } & 43 & 57 & 75 \\ \text { Russia (Omsk) } & 40 & 60 & 100 \\ \text { Eastern Germany } & 70 & 30 & 103 \\ & & & \\ \text { United States } & 79 & 21 & 116 \\ \text { Western Germany } & 65 & 35 & 110\end{array}$

H13. When you have to deal with officials at some government organization or institution, do you often feel distressed or humiliated after that?

Responses in percent

$\begin{array}{lccc} & \text { Yes } & \text { No } & \begin{array}{c}\text { Survey } \\ \text { size }\end{array} \\ \text { Ukraine (pre-coup) } & 62 & 38 & 99 \\ \text { Russia (Omsk) } & 68 & 32 & 111 \\ \text { United States } & 49 & 51 & 122\end{array}$

The three questions above provide evidence of the greater unresponsiveness of authorities in ex-communist countries. A distinct difference in situation is suggested by the likely response that average people expect in formal situations. ${ }^{29}$

The question remains why people in control or representing institutions in ex-communist countries behave so unhelpfully in formal situations. It is not easy to pinpoint the situational influences that might cause authorities to behave as they do-certainly not from a questionnaire given to the general population. Nonetheless, we can ask our respondents whether they perceive that the incentive system encourages helpful behavior in formal situations. That was our motivation for the following question:

H12. Imagine that you enter a shop and the salesman tries very hard to please you. Would you suspect that since he tries so hard he must be foolish or behaving strangely?

29. These results confirm other evidence, provided by surveys by DiFranceisco and Gitelman (1984). They asked, "Let's assume that a local soviet is considering a new law which you feel is unjust. Could you do anything about it?" Only 7 percent of former Soviet citizens in a sample of émigrés said yes, compared to 51 percent of Italian subjects who were asked a similar question (p. 609). 
Responses in percent

$\begin{array}{lccc} & \text { Yes } & \text { No } & \begin{array}{c}\text { Survey } \\ \text { size }\end{array} \\ \text { Ukraine (pre-coup) } & 40 & 60 & 113 \\ \text { Russia (Omsk) } & 50 & 50 & 120 \\ \text { United States } & 25 & 75 & 121\end{array}$

From our personal experiences, we expected even bigger differences in responses between the United States and the ex-communist countries than we found. Nonetheless, the differences are in the direction we hypothesized: more people in the ex-communist countries feel that someone in authority who tries hard must be foolish, implying that no incentives exist for people to try hard.

\section{Attitudinal Influences on Everyday Behavior}

To learn about differences in attitudes across countries, we took care to prevent the situation from affecting answers to our questions. Our first attempt was to question respondents about basic values, thereby abstracting from the current economic situation:

M11. Which of the following achievements would please you more?

A. You win fortune without fame: you make enough money through successful business dealings so that you can live comfortably for the rest of your life.

B. You win fame without fortune: for example, you win a medal at the Olympics or you become a respected journalist or scholar.

Responses in percent

$\begin{array}{lccc} & \begin{array}{c}\text { Fortune } \\ \text { without } \\ \text { fame }\end{array} & \begin{array}{c}\text { Fame } \\ \text { without } \\ \text { fortune }\end{array} & \begin{array}{c}\text { Survey } \\ \text { size }\end{array} \\ \text { Ukraine (pre-coup) } & 67 & 33 & 90 \\ \text { Russia (Moscow) } & 65 & 35 & 92 \\ \text { Russia (Omsk) } & 81 & 19 & 107 \\ & & & \\ \text { U.S.A. (New York) } & 54 & 46 & 117 \\ \text { Japan (Tokyo) } & 68 & 32 & 126\end{array}$


Little difference across countries appears in the responses: the exception is Omsk, where money appears to be most important. Virtually no difference in answers appears to exist between Japan and Ukraine or Japan and Moscow.

Of course, our assumption that this question probes basic values could be questioned. The economic situation may affect answers if people in poorer countries have a more pressing reason to acquire wealth. On the other hand, the meaning of the term "rich" may be dependent on the level of wealth that one currently enjoys. Thus the direction of any bias is unclear.

We can more completely control for economic constraints by referring to a life-and-death decision. The following question probes attitudes toward risk:

H4. Imagine you are suddenly ill. Your illness generally does not interfere with your work and does not prevent you from leading a normal life, but you always feel tired, go to bed early, and you are often in a bad mood because of that. The doctors tell you that this tiredness will continue your whole life unless you decide to undergo a surgical operation. (Imagine that you have complete trust in the doctors and you doubt neither their diagnosis, nor the proposed method of treatment.) The operation will completely cure you, but it is risky: there is one chance in four that you will die. Would you decide to undergo this operation?

Responses in percent

$\begin{array}{lccc} & \begin{array}{c}\text { Yes, } \\ \text { take risk }\end{array} & \begin{array}{c}\text { No, } \\ \text { avoid risk }\end{array} & \begin{array}{c}\text { Survey } \\ \text { size }\end{array} \\ \text { Ukraine (pre-coup) } & 61 & 39 & 105 \\ \text { Russia (Omsk) } & 58 & 42 & 97 \\ \text { United States } & 59 & 41 & 119\end{array}$

Virtually no difference across countries appears in the responses.

Some leisure choices also seem free from influences from the economic situation, so we posed the following question:

H3. What would bring you more pleasure: an opportunity to see a town you have never been to or to spend a relaxed day at home? 
Responses in percent

$\begin{array}{lccc} & \begin{array}{c}\text { See } a \\ \text { new town }\end{array} & \begin{array}{c}\text { Spend } a \\ \text { day at home }\end{array} & \begin{array}{c}\text { Survey } \\ \text { size }\end{array} \\ \text { Ukraine (pre-coup) } & 74 & 26 & 121 \\ \text { Russia (Omsk) } & 68 & 32 & 118 \\ \text { Eastern Germany } & 65 & 35 & 129 \\ & & & \\ \text { United States } & 62 & 38 & 123 \\ \text { Western Germany } & 67 & 33 & 132\end{array}$

Once again, little difference appears between the answers, suggesting that people everywhere have about the same degree of wanderlust. However, the possibility exists that the answers may be influenced by economic constraints, even though the question does not imply that the decision to travel will entail any costs. For example, Ukrainians, who reported more often that they would like to visit a new city, may, because of their current economic hardships, have greater need for a vacation or the opportunity to shop elsewhere to find scarce goods or be more starved for the stimulation of travel. Nonetheless, we think that answers to a question couched in such general terms are likely to indicate general personality traits, and in this area, we find little difference across countries.

To avoid any possibility that economic constraints were a factor in the decision to travel, we posed another question. This query assumed that the trip had been made and asked about a form of self-assertion that is not even remotely connected to any economic situation:

H8. M10. Imagine that you are on a tour to a town you have never been to together with ten fellow tourists. None of you knows how to get to the train station where your train is leaving in half an hour. Would you like to take the map in your hands yourself and start asking local residents for directions? Or you would be more comfortable if somebody else does it?

Responses in percent

$\begin{array}{lccc} & \begin{array}{c}\text { Would take } \\ \text { the map }\end{array} & \begin{array}{c}\text { Would rely } \\ \text { on others }\end{array} & \begin{array}{c}\text { Survey } \\ \text { size }\end{array} \\ \text { Ukraine (pre-coup) } & 76 & 24 & 231 \\ \text { Russia (Omsk) } & 84 & 16 & 225 \\ \text { Eastern Germany } & 97 & 3 & 131 \\ & & & \\ \text { United States } & 81 & 19 & 123 \\ \text { Western Germany } & 97 & 3 & 133\end{array}$


Again, little difference appears between answers in ex-communist and advanced capitalist countries. What is striking is that the Germans are not at all shy about asking for directions; the pattern is the same for eastern Germans and western Germans.

The following question was written to help us learn about attitudes toward day-to-day business activities. The question aims to ascertain differences in people's willingness to undertake everyday activities that resemble business activities. We thought that organizing a birthday party might be such an activity:

M6. Suppose that one of your colleagues, with whom you get along well, is having a fortieth birthday. Your department is going to have a small party on this occasion. Would you agree to take the trouble and responsibility to organize the party?

Responses in percent

$\begin{array}{lccc} & & & \text { Survey } \\ \text { Ukes } & \text { No } & \text { size } \\ \text { Ukraine (pre-coup) } & 59 & 41 & 101 \\ \text { United States } & 85 & 16 & 124\end{array}$

Here we see a substantial difference. The Ukrainians appear less willing to undertake this sort of "entrepreneurial" activity. But we were concerned that the answer might reflect differences in cultural attitudes toward friendship or social obligations, or the ability to turn down requests from friends. Also, the costs of organizing a party may be very different in ex-communist countries, where the organizer may have to spend a long time waiting in lines or searching for scarce commodities. Thus we altered the question in subsequent questionnaires to assume that respondents will help throw the party. We asked whether respondents would chose a more assertive role (giving a speech) rather than a background role (cleaning up afterwards):

M6a. A group of people where you work is planning a (small) retirement party for a friend of yours. You have agreed to help out. Which of the following tasks would you prefer to do? 
Responses in percent

$\begin{array}{lccc} & \begin{array}{c}\text { Give } \\ \text { small speech }\end{array} & \begin{array}{c}\text { Clean up } \\ \text { after the party }\end{array} & \begin{array}{c}\text { Survey } \\ \text { size }\end{array} \\ \text { Ukraine (post-coup) } & 47 & 53 & 77 \\ \text { Russia (Omsk) } & 59 & 41 & 74 \\ \text { Eastern Germany } & 52 & 48 & 128 \\ \text { Western Germany } & 58 & 42 & 130\end{array}$

Some differences appear, but the differences between the ex-communist economies and the advanced capitalist economy are not substantial or consistent.

To summarize this section, we would say that while the results are hardly definitive, they are substantial enough to suggest that the gross differences in attitudes alleged by many do not exist.

\section{Survey Results about Labor Market Behavior}

Some of the most important economic decisions that general surveys of the population can illuminate are decisions about the labor market. An important issue facing workers in ex-communist countries today is whether to take a job in the private sector, whether to support the privatization of their enterprise, and whether to give political support to national efforts at privatization that would switch their own jobs into the competitive private sector. In our surveys, we asked people to describe the situation as they perceive it. Then we probed attitudinal differences that might relate to their decisions.

\section{Situational Influences on Labor Market Behavior}

We begin by documenting the relative lack of incentives for hard and productive work in government jobs in the ex-communist countries. Then we present some evidence that more than fear of hard work is involved in people's decision to move to the private sector.

The following six questions were phrased to discover to what extent people perceive government jobs to be sinecures:

K7. Do you agree with the following assertion: "The most capable and energetic people are quitting work in government enterprises and organiza- 
tions and are starting to work in cooperatives, private enterprises, and so forth" ? $^{30}$

Responses in percent

$\begin{array}{lccc} & & & \text { Survey } \\ & \text { Yes } & \text { No } & \text { size } \\ \text { Ukraine (pre-coup) } & 67 & 33 & 112 \\ \text { Russia (Omsk) } & 65 & 35 & 116\end{array}$

K11. Do you agree with the following assertion: "If someone is lazy or works badly, they will fire him sooner in a cooperative than in a government enterprise"?

Responses in percent

$\begin{array}{lcrc} & & & \text { Survey } \\ & \text { Yes } & \text { No } & \text { size } \\ \text { Ukraine (pre-coup) } & 93 & 7 & 113 \\ \text { Russia (Omsk) } & 79 & 21 & 111\end{array}$

H10. Suppose that you or one of your fellow workers is twenty minutes late for work. How would your boss react to this-would he not take notice or would he give you a dressing down (reprimand)?

Responses in percent

$\begin{array}{lccc} & & & \text { Survey } \\ \text { Unkraine (pre-coup) } & 35 & \text { Reprimand } & \text { size } \\ \text { Russia (Omsk) } & 58 & 42 & 92 \\ \text { United States } & 31 & 69 & 106\end{array}$

H7. Imagine that you work at a TV repair shop. While repairing a TV set you have made a mistake and it broke again. The angry customer comes to talk to your boss. What do you think your boss is most likely to do in this situation?

A. Would agree with the client and make you fix it.

B. Would defend you and try to persuade the client that it is his own fault.

30. In the Soviet Union, the term "cooperative" was a euphemism for "private firm. The term was conceived while political support for private firms was less widespread. Today, the term is mostly obsolete, but it is still commonly used in casual discourse to refer to any private firm. 
Responses in percent

$\begin{array}{lccc} & \begin{array}{c}\text { Agree } \\ \text { with client }\end{array} & \text { Defend you } & \begin{array}{c}\text { Survey } \\ \text { size }\end{array} \\ \text { Ukraine (pre-coup) } & 74 & 26 & 98 \\ \text { Russia (Omsk) } & 77 & 23 & 100 \\ \text { United States } & 84 & 16 & 119\end{array}$

K6. In your opinion, where are the better jobs for people who have about the same skills and abilities as you do: in the government sector or the private sector?

Responses in percent

$\begin{array}{lccr} & & & \text { Survey } \\ \text { Ukraine (pre-coup) } & 44 & \text { Private sector } & \text { size } \\ \text { Russia (Omsk) } & 34 & 66 & 99 \\ \text { United States } & 23 & 77 & 106\end{array}$

K10. Do you agree with the following statement: "Those who work for private businesses are working much harder than those who work in government organizations or enterprises"?

Responses in percent

$\begin{array}{lccc} & \text { Agree } & \text { Disagree } & \begin{array}{c}\text { Survey } \\ \text { size }\end{array} \\ \text { Ukraine (pre-coup) } & 63 & 37 & 103 \\ \text { Russia (Omsk) } & 64 & 36 & 110 \\ \text { United States } & 52 & 48 & 124\end{array}$

The answers to these six questions establish that respondents from ex-communist countries, more so than their U.S. counterparts, view government workers (the great majority of workers) as relatively protected from discipline. Accordingly, respondents in the ex-communist countries tend to view a move to the private sector as a relatively bold and potentially risky act.

However, it does not follow that most people in ex-communist countries think that the relatively high degree of protection for government workers is appropriate:

C3. Which of the following qualities is more important for the manager of a company? 
A. The manager must show goodwill in his relation to workers and win their friendship.

B. The manager must be a strict enforcer of work discipline, giving incentives to hard workers and punishing laggards.

Responses in percent

$\begin{array}{lccc} & \begin{array}{c}\text { Show } \\ \text { goodwill }\end{array} & \begin{array}{c}\text { Enforce } \\ \text { strictly }\end{array} & \begin{array}{c}\text { Survey } \\ \text { size }\end{array} \\ \text { Russia (Moscow) } & 33 & 68 & 112 \\ \text { U.S.A. (New York) } & 49 & 51 & 109 \\ \text { Japan (Tokyo) } & 61 & 39 & 126\end{array}$

The respondents from ex-communist countries certainly see the need for strict managers. (It is perhaps odd that the Japanese are the least convinced that managers must be strict. This may reflect differing standards across countries as to what constitutes a "strict" manager, or it may reflect the greater strictness of managers in Japan.)

It also does not follow that the large number of people who are remaining in their government jobs should be interpreted as harboring any timidity or tendency to avoid work. They must cope with other aspects of their employment situation beyond merely the decision to work harder and take risks. Most basically, workers may be unable to find a job in the private sector. The following question was modeled after the question used by the U.S. Bureau of Labor Statistics to define unemployment, except that we narrowed it to ask only if respondents sought jobs in the private sector:

K4. In the last four weeks, did you try to find a job in a cooperative or private enterprise or joint venture?

Responses in percent

$\begin{array}{lcccc} & & & \text { Already work } & \text { Survey } \\ & \text { Yes } & \text { No } & \text { in cooperative } & \text { size } \\ \text { Ukraine (pre-coup) } & 11 & 82 & 7 & 121 \\ \text { Russia (Omsk) } & 13 & 76 & 11 & 125\end{array}$

We think the proportion answering yes seems rather high; more respondents sought work in the private sector in the four weeks preceding the survey than already worked in the private sector.

The following question sought to identify other issues that concern workers when they contemplate moving to the private sector: 
K9. Suppose that you have worked all your life in a government establishment or institution and now you want to work in a cooperative. There, your pay will be much higher. In making this decision, what worries you the most? I will read you now five variants of concerns, and you are to choose the two that seem to you most important.

A. Many people are hostile to cooperatives and private enterprises, and some of my friends and relatives wouldn't support it.

B. It isn't clear whether today's cooperatives can survive competition.

C. I couldn't count on the support of my former coworkers, especially in difficult times.

D. If I changed my mind and wanted to go back, it would be hard to establish my former position and my former authority at work.

E. I would lose my chance to receive zakazi, free trips, quality medical care, and other benefits that I now have in our enterprise. ${ }^{31}$

Responses in percent

\begin{tabular}{lcccccc} 
& & & & & \multicolumn{2}{c}{ Survey } \\
Ukraine (pre-coup) & $A$ & $B$ & $C$ & $D$ & $E$ & size \\
Russia (Omsk) & 14 & 36 & 11 & 24 & 14 & 140 \\
& 17 & 37 & 12 & 16 & 18 & 153
\end{tabular}

Here is a substantial list of concerns that indicate reasons to doubt that a move to the private sector would be wise, even for hard-working, adventuresome workers. The most important of these reasons in Ukraine and Russia is the fear that today's cooperatives will not be able to survive competition. Thus concerns about the economic outlook for the market economy rank high as rational reasons to remain in stable and secure government jobs. We shall discuss these concerns further below.

\section{Attitudinal Influences on Labor Market Behavior}

When we probe labor market behavior, it is difficult to write questions that hold the situation constant because people are so familiar with their own markets and are likely to assume that the hypothetical situation shares the characteristics of their own markets. To ascertain whether any difference in risk-taking behavior in the labor market exists across countries, we proceeded by asking a rather long question that spelled out the situation in some detail:

31. Zakazi are special offers of goods to workers at government expense; they enable workers to obtain goods of generally higher quality without extensive searching or queuing. 
C12. Imagine that you are offered a new job that increased your salary by 50 percent. The new job is no more difficult than your current job, but not everyone is good at this line of work. It could turn out that after a year or two in this new job you will be told that you are not doing well in the job and will be let go. Your chances of keeping the job and your chances of losing the job are about equal. Given this situation, would you take the risky, high-paying new job? In answering, assume that if your employers let you go, you could, after some time, find something more or less similar to your old job.

Responses in percent

$\begin{array}{lccc} & \text { Yes } & \text { No } & \begin{array}{c}\text { Survey } \\ \text { size }\end{array} \\ \text { Russia (Moscow) } & 52 & 48 & 117 \\ \text { U.S.A. (New York) } & 79 & 21 & 117 \\ \text { Japan (Tokyo) } & 60 & 40 & 126\end{array}$

A substantial difference occurs between New Yorkers and Muscovites: New Yorkers are more willing to take the job. Almost half the Muscovites would turn down the demanding new job-a troubling response given our concern with lack of work motivation in ex-communist countries. Still, the result is puzzling because the Japanese seem to resemble the Russians more than the Americans.

Despite our effort to write a question that spelled out the situation in great detail, we were not entirely confident that the disparity in response between Russians and Americans provided any genuine evidence of differences in attitudes. The different responses might represent a different reaction to the figure of 50 percent. Some Russians who discussed this question and the results with us said that 50 percent was small. Offers by private firms and cooperatives of 200 percent increases in pay do not seem at all unusual in Russia, under current conditions of economic change. The fact that 200 percent increases are commonly offered could mean that this is the reservation price in the Russian market, caused by the higher costs that Russians may associate with such job shifts. Or it could reflect a problem with the base to which respondents attach the 50 percent pay hike. In 1990, when the question was asked, Russians faced repressed inflation and severe nonprice rationing; these conditions may have made a 50 percent increase in pay translate into a smaller increase in the standard of living. 
Because of this ambiguity, we rephrased the question to refer not to a 50 percent increase in pay but to a 50 percent increase in one's standard of living; we used the revised question in subsequent surveys. (Our later surveys in the former Soviet Union were in Ukraine and Omsk, so the sample is not entirely comparable. However, our later surveys allowed us to get a broader comparison of answers to this question, including responses from eastern and western Germany.)

H6. Imagine you are offered a new job where you would be paid much more than now, so that in general your standard of living will increase by half, 50 percent. The new job is no more difficult than your current job, but not everyone is good at this line of work. It could turn out that after a year or two in this new job you will be told that you are not doing well in the job and you will be let go. Your chances of keeping the job and your chances of losing the job are about equal. Given this situation, would you take the risky, high-paying job? In answering, assume that if your employers let you go, you could, after some time, find something more or less similar to your current job.

Responses in percent

$\begin{array}{lccc} & \text { Yes } & \text { No } & \begin{array}{c}\text { Survey } \\ \text { size }\end{array} \\ \text { Ukraine (pre-coup) } & 68 & 32 & 110 \\ \text { Russia (Omsk) } & 42 & 58 & 124 \\ \text { Eastern Germany } & 47 & 53 & 131 \\ \text { United States } & 63 & 38 & 120 \\ \text { Western Germany } & 51 & 49 & 135\end{array}$

With this revised wording, the spread between the Russian and U.S. answers is about the same as with question $\mathrm{C} 12$ above, although fewer respondents in both countries said yes to this question. This might be construed as confirming the results to the previous question. However, some puzzles emerge: respondents in another ex-communist country, Ukraine, show even more willingness to take the high-paying job than did respondents in either advanced capitalist country. Moreover, little difference occurs between responses from eastern Germany and western Germany; respondents in both countries were less likely to say that they would take the job. Thus these results paint no clear picture about differences between ex-communist and advanced capitalist countries as a group. 
We can compare people's relative willingness to trade marginal increases in pay for marginal increases in work effort. We offered respondents the following scenario: ${ }^{32}$

B9. Suppose that for certain reasons you are offered a ten percent increase in the duties you perform at your work place with the following terms: your workweek will be increased by one-tenth (say, you will work an additional half day) and your take-home pay will also increase by ten percent. If you take this offer, this has no other effects on your prospects for promotion or relations with co-workers. Do you consider it attractive to have less free time, but more money so that you would take this offer, or would you decide to reject it?
A. I will definitely reject the offer.
B. I will be more or less indifferent.
C. I will definitely accept the offer.

Responses in percent

$\begin{array}{lcccc} & \text { Reject } & \text { Indifferent } & \text { Accept } & \begin{array}{c}\text { Survey } \\ \text { size }\end{array} \\ \text { Russia (Moscow) } & 62 & 16 & 23 & 120 \\ & & & & \\ \text { U.S.A. (New York) } & 44 & 14 & 43 & 115 \\ \text { Japan (Tokyo) } & 33 & 45 & 22 & 126\end{array}$

The Americans and Japanese were split on this marginal choice (which may be good news for the textbook model of labor supply), while a large majority of Soviets rejected it. Perhaps incentives actually are weaker for Russian workers.

However, a qualification is in order: when offered a scenario identical to the previous one in every respect but suggesting a marginal reduction in effort and pay, Russians gave seemingly inconsistent answers:

A6. Suppose that for certain reasons you are offered a ten percent reduction of the duties you perform at your work place with the following terms: your workweek will be cut by one-tenth (say, you will have an additional half a day free) but your take-home pay will also decline by ten percent. If you take this offer, this has no other effects on your prospects for promotion or relations with co-workers. Do you consider it attractive to have

32. Questions similar to B9 and A6 were asked in the U.S. Current Population Survey (CPS), the Panel Study of Income Dynamics, and the Survey of Work Reduction (SWR) supplement to the Canadian Labor Force Survey. Twenty-eight percent of workers questioned in the CPS, and two-thirds of workers questioned in the SWR, wanted to work more hours at the current wage. These data are analyzed by Kahn and Lang (1989). 
more free time, but less money so that you would take this offer, or would you decide to reject it?
A. I will definitely reject the offer.
B. I will be more or less indifferent.
C. I will definitely accept the offer.

Responses in percent

$\begin{array}{lcccc} & \text { Reject } & \text { Indifferent } & \text { Accept } & \begin{array}{c}\text { Survey } \\ \text { size }\end{array} \\ \text { Russia (Moscow) } & 51 & 21 & 28 & 115 \\ \text { U.S.A. (New York) } & 58 & 11 & 31 & 116\end{array}$

From the Russians' answers to the preceding question (B9), one could have expected that the Russians would have been very likely to accept the offer.

On balance, we are inclined to conclude that we have found no consistent evidence that people in ex-communist countries are substantially less inclined to respond to labor market incentives. Perhaps, though, our inability to find a difference is a weakness of our method; labor market decisions may be too complicated for the methods we use. It may be impossible to abstract from situational factors and still make our questions relevant to labor market behavior.

\section{Survey Results about Entrepreneurship, Investment, and Saving}

Does the situation in the ex-communist countries discourage people from taking risks, acting entrepreneurial, making long-term investments, and saving? Or do their underlying attitudes hold them back from undertaking such economic activity? We administered a series of questions to find out whether important intercountry differences exist, first for situational factors, and then for attitudinal ones.

\section{Situational Influences on Entrepreneurship and Investment}

A fundamental situational question about how a market system functions is whether the government that regulates this system allows people to earn and keep profits. The following question probed respondents' reactions to government interference: 
H14. Do you agree with the following statement: "The government can give so much trouble and nuisance to rich people that it spoils all the pleasure that the money may bring"?

Responses in percent

$\begin{array}{lccc} & \text { Yes } & \text { No } & \begin{array}{c}\text { Survey } \\ \text { size }\end{array} \\ \text { Ukraine (pre-coup) } & 65 & 35 & 91 \\ \text { Ukraine (post-coup) } & 62 & 38 & 106 \\ \text { Russia (Omsk) } & 55 & 45 & 98 \\ \text { Eastern Germany } & 40 & 60 & 124 \\ \text { United States } & 38 & 62 & 122 \\ \text { Western Germany } & 37 & 63 & 131\end{array}$

We find these results striking. At face value, the answers imply that most people in Russia and Ukraine (although not in eastern Germany) think that it might not be worth trying to get rich, even if one could be assured that one could grow wealthy. We do not know from these answers how likely such government interference is thought to be. Nonetheless, this evidence suggests that the profit incentive will be weaker in Ukraine and Russia.

Some people have another reason to fear that they may not be able to enjoy the benefits of profits: they are concerned that government policy will change and the government will take their profits away from them, as the following question reveals.

D03. How likely do you think it is that in the next five years the government will, in some way, nationalize (that is, take over) most private businesses with little or no compensation to owners? Is that quite likely, possible, unlikely, or impossible?

Responses in percent

$\begin{array}{lccccc} & \text { Quite } & & & & \text { Survey } \\ & \text { likely } & \text { Possible } & \text { Unlikely } & \text { Impossible } & \text { size } \\ \text { Ukraine (pre-coup) } & 9 & 41 & 32 & 18 & 104 \\ \text { Ukraine (post-coup) } & 17 & 30 & 35 & 19 & 118 \\ \text { Russia (Moscow) } & 20 & 40 & 29 & 11 & 114 \\ \text { Russia (Omsk) } & 18 & 29 & 38 & 15 & 111 \\ & & & & & \\ \text { U.S.A. (New York) } & 5 & 11 & 53 & 31 & 118 \\ \text { U.S.A. } & 5 & 25 & 52 & 18 & 126\end{array}$


People in ex-communist countries tend to pick "quite likely" more often than their U.S. counterparts. This response is consistent with the result noted to the previous question (H14): both sets of answers indicate that people in ex-communist countries view government as possibly spoiling the pleasure they could derive from getting rich. Moreover, in those countries, people may have worse fears than nationalization:

D05. Please evaluate how likely the following is from your point of view: After five years or even earlier the country will return to Stalinism, the situation in the country will become so hostile to cooperatives and private enterprises that current owners will wind up in gulags and prison.

Responses in percent

\begin{tabular}{lcccccc} 
& Quite & & & \multicolumn{2}{c}{ Survey } \\
& likely & Possible & Unlikely & Impossible & size \\
Ukraine (pre-coup) & 7 & 16 & 45 & 32 & 100 \\
Ukraine (post-coup) & 14 & 17 & 31 & 38 & 119 \\
Russia (Omsk) & 11 & 30 & 23 & 37 & 112
\end{tabular}

These questions imply a strange persistence of fears of Stalinism: substantial concerns surface even in the Omsk survey, given in February 1992, several months after the Soviet Union collapsed. We were surprised to see that fears of a return to Stalinism increased in Ukraine after the coup. Perhaps respondents interpreted "Stalinism" broadly as referring to analogous sorts of repression.

Consistent with this fear of Stalinism is a finding that some people are still trying to maintain some of the old ideological purity:

M5. Some people think that at work and in other formal situations, it's better to keep to traditional ideological principles and not speak or do anything that looks too "capitalist." In your opinion, does such a view affect your actions?

Responses in percent

$\begin{array}{lccc} & \text { Yes } & \text { No } & \begin{array}{c}\text { Survey } \\ \text { size }\end{array} \\ \text { Ukraine (pre-coup) } & 33 & 67 & 88 \\ \text { Russia (Omsk) } & 35 & 65 & 84\end{array}$

One-third of respondents in Ukraine and Russia said yes, certainly more than might be expected if one assumed that many people believed that the current government and legal system were assured for the future. 
This view is accompanied by lingering fears of actual civil war:

D04. In the course of the next five years, there will be a real civil war in the country, in which thousands of people will die.

Responses in percent

\begin{tabular}{lccccc} 
& Quite & & & \multicolumn{2}{c}{ Survey } \\
& likely & Possible & Unlikely & Impossible & size \\
Ukraine (pre-coup) & 6 & 33 & 33 & 28 & 105 \\
Ukraine (post-coup) & 9 & 25 & 41 & 26 & 113 \\
Russia (Omsk) & 17 & 41 & 28 & 14 & 116
\end{tabular}

It is unclear what fear of civil war should mean for entrepreneurs, although it certainly should increase risk.

People in the ex-communist countries also have a less optimistic economic outlook, as the following question indicates:

D02. How likely do you think it is that during the next five years the standard of living could fall dramatically: people will have less food, they will have less clothing and other goods, and the quality of the goods also will deteriorate substantially? How likely is that?

Responses in percent

\begin{tabular}{lccccc} 
& Quite & & & \multicolumn{2}{c}{ Survey } \\
& likely & Possible & Unlikely & Impossible & size \\
Ukraine (pre-coup) & 38 & 43 & 15 & 4 & 106 \\
Ukraine (post-coup) & 36 & 37 & 24 & 3 & 123 \\
Russia (Omsk) & 32 & 38 & 26 & 4 & 124 \\
Eastern Germany & 1 & 24 & 58 & 17 & 129 \\
& & & & & \\
United States & 13 & 49 & 35 & 2 & 126 \\
Western Germany & 3 & 40 & 52 & 5 & 133
\end{tabular}

More people thought that this economic disaster was quite likely in the ex-communist countries. The exception is eastern Germany, where almost boundless optimism seems to exist.

Respondents in ex-communist countries expressed some hope about rapid economic progress. However, only a minority of respondents in the following question expressed strong optimism:

D01. Please evaluate how likely it is, from your point of view, that the next five years will be a period of rapid growth of cooperatives and private enterprises. Many government enterprises will be privatized, so that after 
five years, the private sector will account for at least half of all production in the country.

Responses in percent

$\begin{array}{lccccc} & \text { Quite } & & & & \text { Survey } \\ & \text { likely } & \text { Possible } & \text { Unlikely } & \text { Impossible } & \text { size } \\ \text { Ukraine (pre-coup) } & 23 & 41 & 29 & 7 & 111 \\ \text { Ukraine (post-coup) } & 30 & 42 & 23 & 5 & 117 \\ \text { Russia (Omsk) } & 23 & 42 & 29 & 7 & 120\end{array}$

We wondered whether people in ex-communist countries and respondents in advanced capitalist countries shared similar views about the stability of their employers:

G16. Do you think that it is likely that the enterprise for which you now work is likely to still be doing business (though possibly in a different institutional arrangement) 10 years from now?

Responses in percent

\begin{tabular}{lccccc} 
& Quite & & & \multicolumn{2}{c}{ Survey } \\
& likely & Possible & Unlikely & Impossible & size \\
Russia (Omsk) & 39 & 21 & 33 & 7 & 120 \\
Eastern Germany & 55 & 31 & 9 & 5 & 130 \\
Western Germany & 79 & 14 & 4 & 2 & 134
\end{tabular}

The Russian respondents expressed quite a bit more pessimism about their own enterprise. This pessimism is coupled with a relatively negative view of the product of one's own enterprise:

$\mathrm{K} 2$. Do you think that the company or organization that you work for produces something valuable to society?

Responses in percent

$\begin{array}{lccc} & \text { Yes } & \text { No } & \begin{array}{c}\text { Survey } \\ \text { size }\end{array} \\ \text { Ukraine (pre-coup) } & 81 & 19 & 98 \\ \text { Russia (Omsk) } & 75 & 25 & 107 \\ \text { United States } & 89 & 11 & 123\end{array}$

Rather more respondents said no in ex-communist countries than in the United States, although the differences between the Russian or Ukraine responses and the U.S. answers were rather less than we had expected. 
We narrowed the question to ask how respondents viewed their own work:

K3. Do you think that at your job you yourself are doing something that is valuable to society?

Responses in percent

$\begin{array}{lccc} & \text { Yes } & \text { No } & \begin{array}{c}\text { Survey } \\ \text { size }\end{array} \\ \text { Ukraine (pre-coup) } & 90 & 10 & 107 \\ \text { Russia (Omsk) } & 68 & 32 & 111 \\ \text { United States } & 89 & 11 & 125\end{array}$

The responses reveal somewhat more pessimism in Russia-pessimism that could discourage people from investing their time and resources in the enterprises where they currently work. No real difference in responses occurred between Ukraine and the United States. Once again, the differences were less dramatic than we expected.

We sought further evidence on the concerns people would have in deciding to open a cooperative. We modeled our question on question K9 above:

M4. Imagine that you are thinking of opening a cooperative in which several people would work. In making this decision, what would concern you most? I will read you five possible concerns, and you are to chose the two that seem to you the most important:

A. Social opinion is hostile to cooperatives and private enterprises, and some of my friends and relatives wouldn't support it.

B. It isn't clear that today's cooperatives and private enterprises will survive competition.

C. The world of business is full of cruel and dishonest people, some as bad as bandits. I would not like to have dealings with them or to turn out to be their victim.

D. Today's government officials and bureaucrats at various levels would put a stick in the wheel of any cooperative or private enterprises. They would interfere with opening a business, getting raw materials, and so on. E. I am afraid that in the future the government will change its politics in relation to cooperatives. In the future, cooperatives and private enterprises might be abolished and the property of their owners confiscated.

Responses in percent

$\begin{array}{lcccccc} & A & B & C & D & E & \begin{array}{c}\text { Survey } \\ \text { size }\end{array} \\ \text { Ukraine (pre-coup) } & 11 & 13 & 22 & 26 & 28 & 180 \\ \text { Russia (Omsk) } & 11 & 20 & 25 & 20 & 24 & 225\end{array}$


Respondents gave substantial weight to concerns about potential government interference and fear of "bandits." Oddly, respondents voiced concerns about competitiveness less often than in answering question $\mathrm{K} 9$, which addressed a decision to change jobs, rather than to start a cooperative.

Perhaps the differences between the ex-communist and advanced capitalist countries are not as stark as one could conceive. However, the direction of the difference is plain: more features of the perceived situation would discourage a rational individual in Russia or Ukraine from undertaking entrepreneurial endeavors or long-term investments. This conclusion does not seem to apply to eastern Germans, who are relatively optimistic. ${ }^{33}$

\section{Attitudinal Influences on Entrepreneurship and Investment}

To measure differences in attitudes about entrepreneurship across countries, we can specify the situation. In the following question, we specified that the results of entrepreneurship would definitely double the respondent's well-being:

H1. Suppose that you have an opportunity to start up your own business that is guaranteed to make you rich: all things considered, the level of your well-being would double. However, you would have to work a lot for this: during the next five years, you would have to work hard fourteen hours a day, six days a week. Would you do it?

Responses in percent

$\begin{array}{lccc} & \text { Yes } & \text { No } & \begin{array}{c}\text { Survey } \\ \text { size }\end{array} \\ \text { Ukraine (pre-coup) } & 57 & 43 & 109 \\ \text { Russia (Omsk) } & 69 & 31 & 126 \\ \text { Eastern Germany } & 62 & 38 & 129 \\ & & & \\ \text { United States } & 67 & 33 & 122 \\ \text { Western Germany } & 38 & 62 & 134\end{array}$

33. The relative optimism of eastern Germans was demonstrated in a different way by a survey that compared eastern and western Germans ("Frauen zurück an den Herd?" Der Spiegel, November 19, 1990, p. 123). Respondents were asked to rate their opinions of future growth prospects in eastern Germany using a 1 to 10 scale, with 1 representing "great hope" and 10 representing "great worry." Eastern German respondents' mean score of 3.8 was more optimistic than western German respondents' mean score of 4.8. 
No great difference emerges between answers from the United States and the ex-communist countries. This result refutes the notion that people in the countries of the former Soviet bloc lack ambition. We do have the odd result, however, that the western Germans turn down the opportunity for riches more than anyone else; at least one advanced capitalist country seems to be short on "ambitious" people. ${ }^{34}$

Perhaps people in ex-communist countries are timid about taking risks when the risks could doom such a demanding, time-consuming enterprise to failure. The psychological risk of losing in such a venture could be very different from the financial risk of losing in, say, financial markets. We asked the next question in a smaller set of countries and only to respondents who answered yes to the previous query:

H2. Suppose now that there is one chance in four that your business will fail and you will be left without any remuneration for your efforts. But if everything goes well-and there are three chances out of four for thisyou would become rich, just as in the previous case. Knowing that, would you still decide to start the business?

Responses in percent

$\begin{array}{lccc} & \text { Yes } & \text { No } & \begin{array}{c}\text { Survey } \\ \text { size }\end{array} \\ \text { Ukraine (pre-coup) } & 80 & 20 & 51 \\ \text { Russia (Omsk) } & 80 & 20 & 74 \\ \text { United States } & 74 & 26 & 82\end{array}$

Again, no real difference in answers emerges between the ex-communist countries and the advanced capitalist country.

We asked respondents whether they would invest their own funds in a risky but potentially lucrative start-up:

D7. Suppose that a group of your friends is starting a business that you think is very risky and could fail-but that might also make investors in that business rich. Would you be tempted to invest a substantial portion of your savings in it?

34. In Omsk, we altered the question for the $M$ questionnaire, replacing "well-being will double" with "well-being will increase five times," with no effect on results. 
Responses in percent

$\begin{array}{lccc} & \text { Yes } & \text { No } & \begin{array}{c}\text { Survey } \\ \text { size }\end{array} \\ \text { Ukraine (pre-coup) } & 47 & 53 & 105 \\ \text { Ukraine (post-coup) } & 42 & 58 & 110 \\ \text { Russia (Moscow) } & 51 & 49 & 122 \\ \text { Russia (Omsk) } & 42 & 58 & 103 \\ \text { Eastern Germany } & 28 & 72 & 127 \\ & & & \\ \text { U.S.A. (New York) } & 33 & 67 & 117 \\ \text { U.S.A. } & 30 & 70 & 122 \\ \text { Western Germany } & 14 & 86 & 132\end{array}$

Here a difference emerges between the ex-communist countries and the advanced capitalist countries: the people in ex-communist countries are more willing to take risks. (While a smaller proportion of eastern Germans answered yes than their U.S. counterparts, they said yes with twice the frequency of their western German counterparts.) These responses may reflect the fact that the ex-communist respondents lack good opportunities to invest their savings. Certainly, the results do not support the popular notion that people in these countries lack a risk-taking mentality and thus cannot advance like people in advanced capitalist nations. This result is important for privatization efforts underway in the ex-communist countries; concerns have been voiced that citizens would be reluctant to invest in privatized enterprises. ${ }^{35}$

We tried another tack: perhaps a difference occurs not so much in people's willingness to work hard or to take risks with their work, but rather in their willingness to take on a position of responsibility in a business. The following question pursued this line of reasoning:

H9. Suppose that you, together with your friend, decided to start up a small business-so small that besides the two of you, no one else would work there and you would have no particular dealings with government officials. You would split the work equally, but each of you would have to choose what he will be doing. One of you would specialize in production: he would perform the tasks of an engineer and a worker. The other would manage the business: he would negotiate supplies of raw materials, would arrange sales of your products through shops, and bear material responsi-

35. Recent experience in Russia is encouraging. In Moscow, some recent initial public offerings have raised from one billion to three billion rubles; individual investors put up about one-third of that sum. 
bility for the general situation at your enterprise. Which role would you choose for yourself?

Responses in percent

$\begin{array}{lccc} & \text { Production } & \text { Management } & \begin{array}{c}\text { Survey } \\ \text { size }\end{array} \\ \text { Ukraine (pre-coup) } & 61 & 39 & 100 \\ \text { Russia (Omsk) } & 62 & 38 & 103 \\ \text { Eastern Germany } & 45 & 55 & 123 \\ \text { United States } & & & \\ \text { Western Germany } & 36 & 64 & 123 \\ & 42 & 58 & 132\end{array}$

Here we see some indication that Russian and Ukrainian respondents are less willing to take on an entrepreneurial role. However, no difference in responses emerged between eastern and western Germans. We included the factor "you would have no particular dealings with government officials" so that respondents from the ex-communist countries would not expect to contend with trouble from a government that possibly was unsympathetic. Nonetheless, we cannot be sure that respondents in the ex-communist countries did not imagine that managing the business would be more onerous in their own country than in advanced capitalist countries.

We probed respondents' perceptions of people in business:

C11. Do you think that it is likely to be difficult to make friends with people who have their own business (as an individual or through a small corporation) and are trying to make a profit?

Responses in percent

$\begin{array}{lccc} & \text { Yes } & \text { No } & \begin{array}{c}\text { Survey } \\ \text { size }\end{array} \\ \text { Russia (Moscow) } & 51 & 50 & 111 \\ & & & \\ \text { U.S.A. (New York) } & 20 & 80 & 121 \\ \text { Japan (Tokyo) } & 43 & 57 & 126\end{array}$

A negative attitude toward business people emerges more frequently in Russia than in the United States. However, a surprising result emerged: the negative attitude is about as prevalent in Japan. Perhaps this result reflects a greater segmentation of Japanese society, where it 
may be more difficult to make friends with people in different social strata.

We wondered whether respondents in the ex-communist countries would advise someone else to become an entrepreneur:

D1. Imagine that your neighbor, a young man of 16 years deciding what he will become, seeks your advice. His abilities and inclinations allow him to choose among the following professions: teacher, officer, manager, or journalist. Which would you advise?

Responses in percent

\begin{tabular}{lccccc} 
& & & & \multicolumn{2}{c}{ Survey } \\
& Teacher & Officer & Manager & Journalist & size \\
Ukraine (pre-coup) & 25 & 16 & 37 & 22 & 106 \\
Ukraine (post-coup) & 16 & 12 & 52 & 20 & 113 \\
Russia (Omsk) & 28 & 12 & 54 & 6 & 108
\end{tabular}

The most popular answer was manager: when advising others, people in ex-communist countries think manager is a good occupation, despite their reservations (in question $\mathrm{H} 9$, above) about assuming a managerial role themselves. Moreover, the proportion choosing manager rose sharply following the coup. More than half the respondents favored a career as manager - a high proportion when the choice was one career in four.

To summarize the results of questions in this section, we find no consistent pattern that people in the ex-communist countries lack ambition or entrepreneurial spirit, and no evidence that people in those countries are reluctant to take risks.

\section{Savings Behavior}

Some people think that because the ex-communist countries place very different constraints on consumers, the saving and investment situation in those countries is qualitatively different than that in advanced capitalist countries. The difference was thought to be especially strong before prices were decontrolled in the former Soviet republics and when severe rationing and repressed inflation were widespread. Before price controls were lifted, it was widely thought that a ruble overhang-a large stock of savings accumulated by people unable to spend the 
money-existed. While this extreme situation no longer exists, the results from some of the questions we asked while prices were controlled may still be of some relevance; some talk about a ruble overhang continues.

In May 1990 we asked Muscovites a couple of questions about saving. These questions do not fit squarely into our situational versus attitudinal paradigm. Nonetheless, they may offer some insights into how the differing economic situation in the ex-communist countries may influence behavior. There is no question that the situation regarding savings has been different in ex-communist countries. In May 1990, people had virtually no opportunity to invest their money. Savings banks offered rates of return on deposits of 2 or 3 percent-rates fixed by law. Consumer loans and mortgage loans were virtually unknown. Pensions provided by the government were usually quite low. There is a question, however, whether this different situation was such as to cause important differences in saving behavior.

We found that about the same proportion of respondents in Russia and the United States saved money in the previous year:

A11. Did you save any money from the income you earned last year?

Responses in percent

$\begin{array}{lccc} & \text { Yes } & \text { No } & \begin{array}{c}\text { Survey } \\ \text { size }\end{array} \\ \text { Russia (Moscow) } & 58 & 42 & 128 \\ \text { U.S.A. (New York) } & 55 & 45 & 117\end{array}$

Still more surprising, people in the two countries gave similar reasons for saving money:

A12. Which of the following is the best explanation why you saved?

A. Because to acquire the things I want takes too much effort. I just couldn't spend the money.

B. I put money away for old age, in case of illness or other unforeseeable circumstances.

C. I saved money so that I will have the means to buy a vacation home, an apartment, automobile, or other such things of long-term use.

D. I hoped that better things will be available for my money in future years. 
Responses in percent

$\begin{array}{lccccc} & & & & & \text { Survey } \\ & A & B & C & D & \text { size } \\ \text { Russia (Moscow) } & 6 & 27 & 50 & 17 & 70 \\ \text { U.S.A. (New York) } & 4 & 41 & 39 & 17 & 54\end{array}$

We thought that the Russian responses might reflect the queuing and huge shortages in the goods markets that Russian consumers face, and thus that Russians might choose responses A and D more often than they chose responses B and C. However, they did not: Russians and Americans chose responses $\mathrm{A}$ and $\mathrm{D}$ in virtually the same proportion. Only a minor difference surfaced: for the Russians, accumulation of savings for major consumer items (response C) was relatively more important, while the precautionary motive to save (response B) was relatively less important. These responses may reflect the underdevelopment of consumer credit in Russia.

From these results, we conclude that there was no bottled-up demand caused by an inability to spend rubles (a ruble overhang). ${ }^{36}$ It would appear that situational factors did not differ so greatly-even during the period of extreme rationing that we observed-to cause much difference in saving behavior.

\section{Gauging the Effects of the Coup Attempt and Subsequent Events}

Many of our results compare responses given just before the August 1991 coup attempt with answers given four months later, when the dissolution of the Soviet Union was already planned and price decontrol was already beginning in Ukraine. ${ }^{37}$ The timing of our first survey was quite fortunate; this good fortune enabled us to learn something about how this major political event affected economic perceptions. Our pre- and post-coup comparisons are an "event study" (to borrow a term from empirical finance) because our two surveys were separated by about the

36. Many, including Cochrane and Ickes (1991), have argued that as long as operative markets exist, even in an economy with much rationing, an inability to spend rubles cannot occur.

37. The red flag was lowered over the Kremlin on December 25, 1991. Price decontrol began in Russia on January 2, 1992, but had started several weeks earlier in Ukraine. 
shortest possible interval of time in which the effects of this major change could become apparent. An event study offers a particular advantage: because the interval of time is sufficiently short and is concentrated upon a period surrounding a particular major change, not much time elapses to let any other factors affect results. Certainly, not enough time passed for deeply ingrained attitudes to change.

In Ukraine after the coup attempt, we found that people seemed slightly more optimistic that the economy might prosper. (The percent choosing the most optimistic answer to a question about the potential for economic growth [question D01] rose from 23 to 30 percent.) However, people barely changed their assessment of the risk of economic catastrophe (see question D02). After the coup attempt, respondents were more likely to urge a young person to pursue a career as a manager. (In question D1, the percent choosing manager rose from 37 to 52 percent.) Ukrainians were somewhat more likely after the coup attempt to think that it is worthwhile to convince their bosses to put a good idea into practice. (Yes answers to question D3 rose from 53 to 63 percent.) After the coup, respondents were slightly less likely to think that the government might ruin all the pleasure from earning money. (Yes answers to question $\mathrm{H} 14$ fell from 65 to 62 percent.)

On the other hand, some evidence suggests that people perceived that some aspects of the situation worsened after the coup attempt. More respondents foresaw a risk of nationalization. (In question D03, the percent indicating that nationalization would be quite likely rose from 9 to 17 percent.) Surprisingly, more people anticipated a Stalinist-style crackdown on business leaders. (The percent choosing quite likely in question D05 rose from 7 to 14 percent.)

To further check our understanding of the differences wrought by the coup attempt, we asked respondents in Kherson to evaluate the impact of the coup on their experiences (as part of our PC questionnaire in December 1991). Their evaluations of the impact did not always closely correspond with the changes in expectations between surveys. The changes in expectations caused by the coup are perhaps too small to be accurately measured with our methods.

From our evidence and experience, we conclude that the dramatic event of the dissolution of the Soviet Union changed situational perceptions-but only somewhat. This evidence suggests that we should temper hopes that situational perceptions can be changed quickly when in- 
Table 2. International Comparisons of Situational Factors

$P$ values, except where indicated

\begin{tabular}{|c|c|c|c|c|c|c|}
\hline \multirow[b]{2}{*}{ Question $^{a}$} & \multicolumn{2}{|c|}{$\begin{array}{c}\text { Ex-communist } \\
\text { versus } \\
\text { advanced capitalist }\end{array}$} & \multicolumn{2}{|c|}{$\begin{array}{c}\text { Eastern Germany } \\
\text { versus } \\
\text { western Germany }\end{array}$} & \multicolumn{2}{|c|}{$\begin{array}{l}\text { Russia } \\
\text { versus } \\
\text { Ukraine }\end{array}$} \\
\hline & $P$ value $e^{b}$ & Direction $^{c}$ & $P$ value ${ }^{b}$ & Direction $^{c}$ & $P$ value ${ }^{b}$ & Direction $^{c}$ \\
\hline D3 & 0.000 & + & $\ldots$ & & 0.740 & - \\
\hline H5 & 0.000 & + & 0.000 & + & 0.140 & + \\
\hline H11 & 0.000 & + & 0.437 & - & 0.690 & + \\
\hline $\mathrm{H} 13$ & 0.004 & + & $\ldots$ & & 0.362 & + \\
\hline $\mathrm{H} 12$ & 0.000 & + & $\ldots$ & & 0.125 & + \\
\hline $\mathrm{H} 10$ & 0.004 & + & $\ldots$ & & 0.001 & + \\
\hline H7 & 0.074 & + & $\ldots$ & & 0.624 & - \\
\hline H14 & 0.000 & + & 0.623 & + & 0.165 & - \\
\hline D03 (1 only) & 0.000 & + & $\ldots$ & & 0.098 & + \\
\hline M5 & $\ldots$ & & $\ldots$ & & 0.782 & + \\
\hline D02 (1 only) & 0.000 & + & 0.249 & - & 0.355 & - \\
\hline G16 & 0.000 & + & 0.000 & + & $\ldots$ & \\
\hline K2 & 0.011 & + & $\ldots$ & & 0.301 & + \\
\hline K3 & 0.017 & + & $\ldots$ & & 0.000 & + \\
\hline
\end{tabular}

Summary statistic ${ }^{d}$

Economic advantage

for second countries

(percent significant)

Economic advantage

for first countries

(percent significant)

0

0

0

Source: Authors' calculations using survey results presented above.

a. Questions appear in the order that they are discussed in the paper.

b. Each $p$ value is the probability, in a sample this size, of obtaining a $z$ statistic whose absolute value is as large as we found. By convention, a result is statistically significant (that is, acceptable as evidence of genuine differences between countries) if the $p$ value is less than 0.050 . The threshold $p$ value should properly be adjusted for sample size, for considerations regarding power, and for the relevant alternative hypothesis. Zero values shown are caused by rounding. The true $p$ value is never zero.

c. A plus sign indicates that the results for this question imply economic disdvantages for the first country listed. A minus sign implies economic disadvantages for the second country listed. The plus and minus signs appear whether or not the answer is statistically significant.

d. The last rows tabulate the proportion of significant + and significant - results.

stitutions change. People in Kherson may have not perceived the importance of the coup attempt in the way we at a distance might have expected. The view that the coup attempt was the most dramatic change in the history of the Soviet Union may have been a perception shared only by Muscovites and Westerners. No major action or significant disruption of everyday life occurred in Kherson at the time of the coup; people might have perceived the event as just another thriller on Mos- 
Table 3. International Comparisons of Attitudinal Factors

$P$ values, except where indicated

\begin{tabular}{|c|c|c|c|c|c|c|}
\hline \multirow[b]{2}{*}{ Question $^{a}$} & \multicolumn{2}{|c|}{$\begin{array}{c}\text { Ex-communist } \\
\text { versus } \\
\text { advanced capitalist }\end{array}$} & \multicolumn{2}{|c|}{$\begin{array}{c}\text { Eastern Germany } \\
\text { versus } \\
\text { western Germany }\end{array}$} & \multicolumn{2}{|c|}{$\begin{array}{l}\text { Russia } \\
\text { versus } \\
\text { Ukraine }\end{array}$} \\
\hline & $P$ value $^{b}$ & Direction $^{c}$ & $P$ value $^{b}$ & Direction $^{c}$ & $P$ value $e^{b}$ & Direction \\
\hline M11 & 0.012 & - & . & & 0.249 & - \\
\hline $\mathrm{H} 4$ & 0.921 & - & . & & 0.664 & + \\
\hline H3 & 0.258 & - & 0.733 & + & 0.307 & + \\
\hline H8 & 0.035 & + & 1.000 & & 0.033 & - \\
\hline M6 & 0.000 & + & $\ldots$ & & $\ldots$ & \\
\hline M6a & 0.296 & + & 0.333 & + & 0.140 & - \\
\hline $\mathrm{C} 12$ & 0.002 & + & $\ldots$ & & $\ldots$ & \\
\hline H6 & 0.218 & + & 0.514 & - & 0.000 & + \\
\hline H1 & 0.006 & - & 0.000 & - & 0.057 & - \\
\hline $\mathrm{H} 2$ & 0.311 & - & $\ldots$ & & 1.000 & \\
\hline D7 & 0.000 & - & 0.006 & - & 0.608 & - \\
\hline H9 & 0.000 & + & 0.629 & + & 0.884 & + \\
\hline C11 & 0.001 & + & $\ldots$ & & $\ldots$ & \\
\hline
\end{tabular}

Summary statistic ${ }^{d}$

Economic advantage for second countries (percent significant)

Economic advantage for first countries (percent significant)

cow television, albeit somewhat unusual. A watershed event may have to be more palpable and dramatic to ordinary citizens, or it may have to offer concrete evidence of the direction of change in the economic situation, before it causes people to substantially change their perceptions of their situation.

\section{Summary of International Evidence on Situational and Attitudinal Factors}

Tables 2 and 3 summarize differences between ex-communist and advanced capitalist countries in situational and attitudinal factors that could affect economic behavior. These tables tabulate all the responses 
that directly reveal evidence of problems that could impede work and other economic activities in a country ${ }^{38}$ Many readers may disagree with the way we group questions and interpret results. Some may argue, for example, that excessive ambition and hard work are not good personality traits and that these traits do not promote happiness and fulfillment. Nonetheless, some quantification of differences based on our (albeit fallible) judgments could prove helpful.

Table 2 examines situational factors. Table 3 examines attitudinal factors. In each table, we compare answers three ways-between excommunist and advanced capitalist countries; between eastern and western Germany; and between Ukraine and Russia. We test whether there is a statistically significant difference between answers in each pair. Our null hypothesis is that there is no significant difference between countries in the number of people who would choose the first answer to the question.

The $p$ value shown for each question is the estimated probability that the difference we observed between countries could be due entirely to chance in our sampling, rather than to a genuine difference in the populations of the countries. The $p$ value does not indicate the potential importance of the difference observed; sometimes a small, not important difference can be statistically significant. Readers can refer to the results of individual questions to judge the importance of the differences in responses.

A plus or a minus sign after the $p$ value indicates the direction of the difference between answers. A plus sign indicates that effective work will be less likely - and thus implies greater economic problems-for the first country (or class of countries) in the column heading. A minus sign indicates greater economic problems for the second country (or class of countries). The bottoms of the tables contain two more sets of statistics: the proportion of the $p$ values that are both statistically significant and imply relative economic advantage for the second country or set of countries; and the proportion of $p$ values that are significant and imply relative economic advantage for the first country or set of countries.

The first two columns in each table show comparisons between ex-

38. The tables omit a few questions asked in ex-communist and advanced capitalist countries. Questions A6, A11, A12, B9, C3, K6, and K10 do not help us to directly draw inferences, in isolation, about the homo sovieticus problem. 
communist countries and advanced capitalist countries. For these results, the proportion of respondents from all ex-communist countries who chose the first answer was compared with the proportion of respondents from all advanced capitalist countries who also chose the first answer. In table 2, a plus sign in the second column indicates that the situation in ex-communist countries is more likely to cause economic problems (because the situation provides less incentive to work hard, to maintain a helpful attitude, or to make long-term investments). In table 3 , a plus sign in the second column indicates instead that people in excommunist countries exhibit the attitudinal traits that we have associated with homo sovieticus: lack of leadership, initiative, adventurousness, or entrepreneurship; and unwillingness to accept responsibility or take risks.

The evidence in table 2 about situations in ex-communist countries is striking. Ninety-two percent of the responses listed in column 1 of table 2 are significant and suggest greater situational problems in the ex-communist countries. On the other hand, the evidence about attitudes presented in table 3 does not reveal such a consistent pattern of difference between ex-communist and advanced capitalist countries; the results seem to point to a relative advantage for ex-communist countries almost as often ( 23 percent) as for advanced capitalist countries ( 38 percent). Thus, we find much more evidence of systematic differences between ex-communist and advanced capitalist countries in situation than in underlying attitude.

The situation in eastern Germany appears more favorable. Comparisons of eastern Germany and western Germany reveal that only 40 percent of the situational questions (table 2, columns 3 and 4 ) yielded results that were significant and suggestive of greater problems for the eastern Germans. Thus the differences in situation between eastern and western Germany are much less striking than the difference between ex-communist and advanced capitalist countries as a group. This is not altogether surprising because eastern Germany has adopted the laws and government of western Germany. The comparisons of attitudes between eastern and western Germany (table 3, columns 3 and 4) work in the opposite direction, indicating an advantage for eastern Germans over western Germans. Taken together, these results provide relatively little net evidence that eastern Germans face greater economic problems than western Germans. 
The comparisons of Russians with Ukrainians also appear in tables 2 and 3 , columns 5 and 6 . These results are not presented as tests of the basic homo sovieticus theme of this paper because Russia and Ukraine are both ex-communist countries. That theme might suggest that no difference in these dimensions should appear between Russia and Ukraine. In fact, we find little statistically significant difference in attitudes between Russia and Ukraine, and only a slight suggestion that Ukraine's situational factors are more favorable than Russia's. However, when evaluating such a modest difference, we should bear in mind that we are looking at evidence from only one city in Ukraine and one or two cities in Russia.

\section{Evaluating Short-Term Outlook and Behavior}

Our evidence suggests that while attitudes in ex-communist countries do not consistently differ from attitudes in advanced capitalist countries, respondents in the two sets of countries consistently differ in their perception of situations. The differences in situation were not always as strong as we expected before we began this study. Nonetheless, our results confirmed that all the differences worked to the disadvantage of the ex-communist countries.

From the results above, it appears that the perceived situation in excommunist countries appears to encourage rational people to assume a relatively short-term mentality: they try to work their way through current problems as easily as possible, but try to avoid making any longterm commitments. We asked several questions to confirm such shorttermism:

D4. Imagine that the company or organization where you work now offers to everyone a chance to go through a voluntary education program. (You would not have to pay for it and it would take place in the evenings after business hours.) You would learn a lot about the way your company operates and how decisions are made by management. You will be able to make friends with a lot of your colleagues. But this knowledge and connections would hardly be of use to you if you quit your present job. Would you like to go through such a program? 
Responses in percent

$\begin{array}{lccc} & \text { Yes } & \text { No } & \begin{array}{c}\text { Survey } \\ \text { size }\end{array} \\ \text { Ukraine (pre-coup) } & 64 & 36 & 106 \\ \text { Ukraine (post-coup) } & 47 & 53 & 114 \\ \text { Russia (Omsk) } & 50 & 50 & 117 \\ \text { United States } & 80 & 20 & 127\end{array}$

Note the wording: the knowledge is company-specific and not useful if the company fails or if the employee quits. Ex-communist respondents were clearly less eager to make this company-specific investment of time. We think this reveals a serious problem in Russia and Ukraine, as do the results of the next question:

D8. Could it happen that in the next few years you would decide to leave the country forever (that is, emigrate)?

Responses in percent

$\begin{array}{lccc} & \text { Yes } & \text { No } & \begin{array}{c}\text { Survey } \\ \text { size }\end{array} \\ \text { Ukraine (pre-coup) } & 14 & 86 & 113 \\ \text { Ukraine (post-coup) } & 19 & 81 & 116 \\ \text { Russia (Omsk) } & 22 & 78 & 110 \\ \text { United States } & 8 & 92 & 126\end{array}$

While the differences between ex-communist and advanced capitalist countries are not as great as one might have expected, the proportion of respondents who said they might emigrate was nearly twice as high in Ukraine and nearly three times as high in Omsk as it was in the United States. This suggests that people in Ukraine and Omsk have a substantially lower incentive to make long-term investments in human capital or make investments specific to the local economy. ${ }^{39}$ The next question also reveals serious short-termism.

39. One might think that emigration from eastern Germany to western Germany would be vastly greater than emigration from the former Soviet Union because Germans do not need to learn a new language. However, in a survey reported by Der Spiegel in 1991, 95 percent of eastern Germans, when asked if they would "continue to remain on the territory of the former GDR," said, "I will, in any event, remain here" or "[I will] probably stay 
G17. Do you feel that you, personally, have been taking more initiative to help your enterprise be an effective on-going business than you did five years ago, or do you find that you are more occupied with other matters?

Responses in percent

$\begin{array}{lccc} & \begin{array}{c}\text { Been taking } \\ \text { more initiative }\end{array} & \begin{array}{c}\text { Occupied with } \\ \text { other matters }\end{array} & \begin{array}{c}\text { Survey } \\ \text { size }\end{array} \\ \text { Russia (Omsk) } & 37 & 63 & 101 \\ \text { Eastern Germany } & 83 & 17 & 121 \\ \text { Western Germany } & 76 & 24 & 116\end{array}$

Here a large and troubling difference emerges between Russia and the advanced capitalist country. However, in eastern Germany, unlike Russia, this problem does not emerge.

An important problem is suggested here for Russia and Ukraine. People there are less prepared to make investments of their time that are specific to their current organization. This short-termism might be a sensible response to a situation in Russia and Ukraine in which many people expect current enterprises to fail (recall the responses to question G16), and some readers may regard these results as unsurprising. Still, we are learning something here about the costs of deferring major economic reforms: the current problematic economic situation does not appear to be producing a return to serious effort or renewed concern for effective work.

A bit of additional evidence about short-term outlook and behavior concerns the decision to start a family, as the next question reveals.

M2. Do you agree with the following assertion? "Because in the near future our economy may fall apart, young people shouldn't start a family and raise children. It is better to wait a few years, until things settle down."

Responses in percent

$\begin{array}{lccc} & & & \text { Survey } \\ & \text { Yes } & \text { No } & \text { size } \\ \text { Ukraine (pre-coup) } & 34 & 66 & 103 \\ \text { Russia (Omsk) } & 46 & 54 & 120\end{array}$

here"; only 5 percent said they would "probably go to the West" or "in any event, go to the West." See "Zehn Jahre bis zum Wohlstand?" Der Spiegel, July 29, 1991, p. 41-49. Akerlof and others (1991) give further evidence of eastern Germans' reluctance to move. 
Nearly half of the Russians and a third of the Ukrainians are pessimistic enough to postpone having children..$^{40}$

\section{Have We Found Homo Sovieticus?}

Our limited evidence implies that attitudinal factors are less important than situational factors in influencing how successfully ex-communist countries will make the transition to market economies. The biggest obstacles to a successful transition do not seem to lie in the basic attitudes or psychological traits held by people in the ex-communist countries. While some differences in attitudes do seem to occur across countries, we do not see evidence to support any designation of the excommunist countries as a group in terms of these differences. Attitudinal differences across countries are complicated and are not easily summarized with broad generalities. We think that it is rather misleading to refer to homo sovieticus as a distinct breed of person.

Some observers worry that people living in ex-communist countries are timid and fearful of change and thus will try to apply political pressure to resist privatizing state enterprises. It is argued that people living in ex-communist countries will resist moving to jobs in productive private firms out of sheer inertia or lack of ambition. Observers worry that unproductive enterprises will survive because people will be willing to remain in such firms and work for low wages, despite better opportunities. We doubt these conclusions. Political pressures may well be exerted against privatization and some people may be reluctant to switch their employers. However, our evidence suggests that the primary reasons will not be greater timidity, fear of change, or lack of ambition in the ex-communist countries.

On the other hand, while our results are not always as dramatic as we expected, our research has consistently confirmed that some problems worthy of concern exist for the ex-communist economies of Russia and Ukraine. These problems are situational, not attitudinal. People trust current institutions relatively less in the ex-communist countries and are

40. Birth rates are declining in Russia. The crude birth rate (number of births per 1,000 people) in Russia was 17.2 in 1987; 16.0 in 1988; 14.6 in 1989; and 13.4 in 1990 (Narodnoye Khozyaistvo v RSFSR, Moscow, 1991). 
less likely to expect their own current efforts to succeed. Because of these problems, Russia and Ukraine exhibit a tendency for short-term outlook and behavior-a tendency that we suspect is more serious than the short-termism that is a feature of current U.S. election debates. People in Russia and Ukraine are more likely to expect the government to create serious problems that will undermine their own efforts to improve their own situation. They are more likely to expect their enterprises to be unrewarding. They are more likely to think that they may need to cut their losses and even emigrate. People there are less willing to make long-term commitments of their time, money, and other resources; to develop skills related to the market economy; and even to have children.

Part of this situational problem might be called a "bad expectations equilibrium." A Keynesian vicious circle may be at work: many people do not invest in the current system because they believe that it will not perform for them; they will not believe that the system will perform for them until they see it perform; their pessimism and reluctance may impede the system, and tend to cause the very disappointments and failures they feared. Perhaps not much can be done to correct a bad expectations equilibrium. Indeed, we do not know how to move out of such equilibriums-which we believe are a factor in the periodic recessions that plague advanced market economies. The problem is that people do not change their expectations quickly, even when confronted with such dramatic events as the dissolution of the Soviet Union.

Another aspect of the situational problem facing Russia and Ukraine is formal laws and regulations. The problematic situation we observe in Russia and Ukraine today in some ways resembles the difficult situation that Germany faced immediately after World War II when "fundamental uncertainty over property rights and the economic rules of the game was significant." ${ }^{\text {"1 }}$ Some help can be provided now by drafting laws, regulations, and corporate charters to encourage people to think that the situation has changed.

Other parts of the situational problem in Russia and Ukraine may be more deeply rooted in popular assumptions about reciprocity, implicit contracts, and social conventions. Why are people in these countries

41. Alexander (1991, p. 17) quotes contemporary observers in Germany at the end of World War II as saying that "there is evident a general hesitancy to make any decisions at all. . . . Let's wait and see. . . . Why should I look for a job now?" 
more likely to think that it is not worth their while to try to convince their boss to put a good idea into practice? The answer may be that different commonly held assumptions exist about a boss' responsibility to reward an employee who presents a good idea-a socially sanctioned implicit contract between boss and employee. Let us hope that the situation will be rectified naturally as firms adopt the management styles that tend to occur in profit-making firms. Managers may learn such styles from Western firms or they may independently discover the advantages of such styles. Alternatively, the situation may be changed only by a kind of "social osmosis" as people learn by observing one another. ${ }^{42}$ In the kind of osmosis we envision, as people encounter and learn about different assumptions held by others, they may gradually change their assumptions about the kind of deal that is naturally struck with others. People may change such assumptions very quickly when they move to an advanced capitalist country and encounter many other people who have different expectations and social conventions. The speed with which such changes occur within the ex-communist countries may be much slower because people will often continue to encounter many others with the old assumptions.

Our study of the ex-communist countries leads us to focus most of our concern on Russia and Ukraine. Eastern Germany is burdened less by the problems we have discovered in the other ex-communist countries. This is not because eastern Germans have different attitudes than Russians or Ukrainians. Rather, eastern Germans have different perceptions as to the economic constraints they face. They are more optimistic, more committed to produce in the current system, and more likely to adopt long-term thinking.

42. See Sah (1991). 


\section{Comments and Discussion}

Sidney G. Winter: Have years of communist rule produced a human character type that is virtually a different species in terms of its motivational stance toward economic activity? If valid, this familiar claim would have dire implications for the prospects for transforming the former Soviet-style economies into Western-style market systems. With limited resources relative to the size of the question, but with a lot of entrepreneurial verve, Robert Shiller, Maxim Boycko, and Vladimir Korobov set out to subject this idea to some empirical scrutiny.

In my view, they largely succeed in achieving their principal objective, delivering a solid blow to the credibility of the homo sovieticus theory. If they have not quite succeeded in establishing that this hominid is an out-and-out fraud like Piltdown man, they have at least shifted the burden of proof very substantially. Anyone who thinks that the legacy of communism includes a deep warping of human nature at the motivational level is now challenged to refine his or her arguments and explain how such reasoning might be reconciled with the evidence in this paper.

Quite apart from its substantive interest, the paper is a notable example of a relatively rare art form in economic inquiry. It is an unpretentious account of the results of a major and novel data-gathering effort. The authors freely concede a number of imperfections and potential limitations of their work, and they make no attempt to paper over the inevitable untidiness of an exploratory project. They also abstain from tying up all the results in a neat bundle. The central contrast between "situational" and "attitudinal" factors influencing behavior provides a spare but adequate theoretical structure for the investigation.

Some years ago, Wassily Leontief published a sharp critique of the 
allocation of effort in economic research. ${ }^{1}$ Those familiar with that critique will recognize that the contribution of Shiller, Boycko, and Korobov represents a genre whose relative thinness Leontief deplored. Many economists, however, are either unfamiliar with Leontief's critique or unsympathetic to it. They will seek to elucidate the potential hazards of relying on these novel data-an effort much facilitated by the openness of the authors on that very point.

By contrast, economists often seem to have inordinate respect for official data relating to familiar economic aggregates, and also for unofficial estimates of what the official data should or would be if such data existed. Such estimates were presented, for example, in Stanley Fischer's paper in this issue, and the paper itself and the discussion of it barely touched on the data reliability issue. While I have no claim to expertise on this issue, I do know something about the earlier situation regarding estimates of economic activity in the former Soviet Union. ${ }^{2}$ All such estimates were tainted with the statistical counterpart of original sin: ultimately, they were all derivative of Soviet administrative statistics that, at their point of origin, were subject to strong incentives favoring deceit over accuracy. I also know that, even in an advanced and stable economy like that of the United States, abundant grounds for skepticism exist regarding the products of the official statistical system. Finally, I do not believe in miracles. If 1,000 equivalents of former U.S. Commissioner of Labor Statistics Janet Norwood had appeared at key points in the Russian bureaucracy and statistical system last September, I can imagine that by now the system would be throwing off the burden of statistical original sin. Absent such a miracle, I literally cannot imagine what sort of process could now be generating economic data that deserved much credence.

It seems that a characteristic imbalance exists in the profession's typical reactions to economic data. Where familiar types of data are concerned, credulity is the norm and few questions are raised about the provenance of the data. When the data are of some unfamiliar type, skepticism arises, and questions about the provenance of the data receive much attention-even when, as in the current case, those questions have been largely preempted by a forthright presentation.

1. Wassily W. Leontief, “Academic Economics," Science, July 9, 1982, p. 904.

2. See, for example, United States General Accounting Office (1991). 
Aside from the fact that it presents an obstacle that the authors must overcome, this issue is largely tangential to the concerns of Shiller, Boycko, and Korobov. I think, however, that it is broadly relevant to the problem of assessing the economic situation in Russia and the other emerging economies. Economists, governments, and international institutions concerned with helping these economies would do well to study the possible application of a variety of economic measurement methods that do not involve reliance on administratively generated data, such as the approach used by Shiller and his colleagues. Use of these alternative methods might ultimately entail a lessened reliance on familiar conceptual categories and a greater dose of "ad hockery." Arguably, however, such an approach is quite appropriate in interpreting the very unfamiliar, chaotic, and rapidly changing situations in these economies.

As I have already suggested, I believe that Shiller, Boycko, and Korobov have established their main point quite convincingly, especially as regards the summary results on situational factors presented in the first column of table 2 . Their evidence shows systematic and significant differences in situational factors that tend to handicap ex-communist countries, relative to advanced capitalist countries. However, the results on attitudinal factors are quite mixed. This supports the view that situational rather than attitudinal factors pose the main obstacle to progress in the emerging economies.

In the exploratory spirit of Shiller and his colleagues, I have examined the data from a different perspective. On casual inspection, it appears that the contrasts among the various panels are not all that imposing, whatever their origin. This point could be more precisely framed as follows: consider your own answer to any of the survey questions to which only two alternative answers are offered. Then, imagine that you are plunked down at random in the middle of one of the settings examined in the surveys. You find that your view on the particular question is opposed by the local population by a margin of more than two-to-one. Can you move to another panel location and be in the majority by at least a two-to-one margin? The answer is no. If your opinion is not locally "respectable" in the sense that at least one-third of the locals agree with you, it is likely that it is a minority opinion everywhere and that it is definitely not a two-to-one dominant opinion anywhere.

In interpreting this pattern and others discussed below, it is useful to recall two of the familiar mechanisms that produce patterns in answers 
to survey questions. For questions relating directly or indirectly to electoral politics, two-party political systems pressure both parties toward the center: what is the point of running if no prospect exists for persuading more than half the voters to your position? For units smaller than entire polities (such as the states of the United States) one expects to see some units voting one way and some the other, often by narrow margins, when the same choice is faced by all (such as presidential elections). Different but not fully disjoint from these "electoral" questions are "pride" questions-ones that tend to evoke characteristically different responses from people of different nationalities, regions, races, religions, or ethnic groups on questions of historical interpretation (whose was the achievement, or who was at fault), or on matters of morals, ethics, or protocol. If the resonances with the past are strong enough, or if communications are good enough so that the "correct" group view is effectively disseminated, pride responses may be evoked on contemporary policy issues, as well. Obviously, pride questions tend to evoke response patterns involving strong intra-group unanimity and strong inter-group differences: consider the attitudes of Italians, Native Americans, and Scandinavians toward Columbus' "discovery" of America in 1492.

The questions that Shiller, Boycko, and Korobov asked are neither electoral nor pride questions; they generally ask what choices are sensible for individuals in everyday life. The different panels are driven neither toward 50-50 splits by electoral politics nor toward opposed 100-0 splits in different panels by pride issues that separate the panels. The results seem to testify to a strong underlying homogeneity in attitudes and perceptions of the human situation in everyday life-significant situational differences among societies notwithstanding. There are hard questions that reveal substantial differences of view in every panel and easy questions that do not. Easy questions tend to be easy everywhere, and the answer is the same. Hard questions evoke split verdicts everywhere, and not by overwhelming margins.

To quantify this impression, I focused on the 30 survey questions involving only two alternatives (ignoring the cases where Russia and Ukraine were the only panels reported) and sorted them into the following four categories:

1. Strong unanimity. All panels favor the same answer by margins of at least two-to-one.

2. Unanimity. All panels favor the same answer, but strong una- 
nimity does not prevail. (I counted a 50-50 split as agreement with the other panels.)

3. Weak division. At least one answer is supported by at least 34 percent of respondents in all panels, but neither strong unanimity nor unanimity prevails.

4. Strong division. No answer commands support by 34 percent or more of respondents in all panels.

As regards strong division, my earlier statement regarding "respectable" opinion anticipated the results: in the 30 cases, no examples of strong division occurred. Six examples of strong unanimity, 11 of unanimity, and 13 of weak division appeared. Among questions exhibiting weak division, four miss unanimity by slender margins, amounting to three percentage points or less in a single country. The 49 percent of Americans who answer "yes" in question H13; the 49 percent of Russians who answer "no" in question D7; and the 47 percent of Ukrainians (post-coup) who express a preference to give a small speech in question M6a or answer "yes" to question D4 are slightly out of step with the view dominant in the other panels asked the same question. A more striking example of weak division is question $\mathrm{H} 1$, which asks about willingness to work very hard for five years if the reward is to definitely double one's living standards. On this question there would be strong unanimity on "yes" if only the Americans and Russians were asked, and unanimity if the western German view were ignored. However, the proportion of western Germans answering "yes" is only 38 percent. This example narrowly misses being a case of strong division, with the Russians leading the pro-hard work side of the split (69 percent) and the western Germans alone on the anti-hard work side. But then, the western Germans are much richer than the Russians to begin with, and unlike most Americans, they are much richer now than they were a generation ago. Come to think of it, they do take a lot of vacation.

In conclusion, let me emphasize what the authors themselves concede regarding the role that situational factors may play in the futures of the emerging economies. While the outlook may be much more favorable than it would be if these countries were actually inhabited by homo sovieticus, it is not on that account a cheerful outlook. Improving the incentives facing individual actors requires breaking out of a "bad expectations equilibrium" through roughly concurrent changes in behavior by many individuals and institutions. As the authors indicate, that will not be an easy thing to bring off. 
Thomas Schelling: This paper by Robert Shiller, Maxim Boycko, and Vladimir Korobov is the first systematic survey of opinion in Russia or Ukraine that I've seen, so it is bound to be the only one attempting to identify attitudes pertinent to the forthcoming market for businesses and jobs. Some of the survey questions are straightforward; others are imaginative efforts to offer parallels-even metaphors-to compare American with Russian responses to hypothetical situations that may reveal something like lasting personality traits. Some of the questions, in my judgment, succeed. Some fail-fail in the sense that I do not see a plausible translation of answers into attitudes. The effort to contrast situational with attitudinal factors makes the most useful distinction; however, I think it does not always work. The authors offer their interpretations, but readers are free to translate the questionnaire results as they please. This was a pioneering enterprise and, like most pioneering enterprises, presents findings that often are puzzling.

My strongest reactions are skeptical; for brevity, I offer only those strongest reactions. I am skeptical of specific questions, not critical of the effort, or even of the results. I think the authors may have been a little incautious in interpreting the results-much less so in the draft being published. Perhaps the reader is better challenged as a result.

One object of this inquiry is attitudes and opinions among Russians and Ukrainians toward entrepreneurship and business management. A random sample is appropriate if we think that popular attitudes of that kind affect the behavior of consumers and workers. If instead we are interested in potential entrepreneurs, we should be trying to sample not the whole population but rather the people who have any likelihood of being in a position to start a new business or manage one. Whether a coal miner would rather be a production manager or a financial manager if he had the opportunity to choose probably is not of much interest to us. It is not obvious to me what fraction of the population we might like to display entrepreneurial spirit: 1 percent; 5 percent; or 20 percent? I suppose a main reason for sampling Americans and Russians for comparison would be that we have some idea whether Americans are insufficiently, excessively, or optimally interested in adventurous acts like switching jobs and starting new businesses.

In approaching the survey results, I didn't really know what to expect of Russians and Ukrainians, but (if I had thought to ask myself) I probably would have had a pretty good idea of what to expect among U.S. respondents on many of the questions. What I find most stunning about 
the survey is that many Americans gave answers that shock me. I have difficulty even comparing Russian results with U.S. results and I am led to wonder how respondents interpreted the questions, particularly when they had to supply instant answers to questions to which they probably had not given much thought.

Consider question H14. "Do you agree with the following statement? 'The government can give so much trouble and nuisance to rich people that it spoils all the pleasure that the money may bring.' "I would have expected that among the very rich in the United States, some respondents would have been so disgruntled with government interference that they might have chosen to agree openly with such an extravagant statement, but it is hard to believe that anybody could really mean it. The 38 percent of Americans who agreed with the statement cannot all be wealthy entrepreneurs who have to cope with U.S. regulatory bodies such as EPA and OSHA and EEOC. Mathematically no more than half of that 38 percent could be in the top income quintile, so I simply cannot find any interpretation of this answer that makes sense for Americans. And if I cannot take the Americans seriously, it is hard to know how to interpret the Russians and the Ukrainians.

Again consider question DO3. "How likely do you think it is that in the next five years the government will, in some way, nationalize (that is, take over) most private businesses with little or no compensation to owners? Is that quite likely, possible, unlikely, or impossible?" Sixtynine percent of New Yorkers consider it not impossible. The ranking of the four possibilities-from "quite likely" at one extreme to "impossible" at the other-puts "unlikely" next to "impossible," but whether the 53 percent of New Yorkers who chose "unlikely" meant more than possible, or something between possible and impossible, is hard to guess. I simply do not know what the New Yorkers had in mind, unless a New Yorker considers almost nothing impossible and will answer "unlikely" to all kinds of outrageous propositions.

Then there is question DO2. "How likely do you think it is that during the next five years the standard of living could fall dramatically: people will have less food, they will have less clothing and other goods, and the quality of the goods also will deteriorate substantially?" Again we have the difficulty of interpreting "possible" and "unlikely," but the answers from the continental United States express a pessimism that I find completely inconsistent with the way Americans behave. Fully 98 percent of 
Americans consider it not impossible and-again, subject to the ranking of the four answers-62 percent consider it not unlikely. It is hard for me to believe they really do.

I even had some difficulty with question D8. "Could it happen that in the next few years you would decide to leave the country forever?" I think I would have found the Ukrainian and Russian figures-both around 20 percent-lower than I expected. Furthermore, I would have thought the figures for those two countries would be at least ten times higher than the figure for the United States. However, the Russian figure is less than triple the U.S. figure and the Ukrainian figure is less than double. Until I can figure out what kinds of Americans we are dealing with, I shall have trouble understanding the Russian and Ukrainian answers. Maybe the key to the U.S. answers is in the formulation, "could it happen," or maybe respondents didn't listen carefully to "in the next few years" and some people who had immigrated to the United States thought of eventually returning to their native countries after they had retired. But if 8 percent of the respondents translates into 10 or 15 million adults who answer that it "could happen" that they would emigrate, it is hard for me to know what they had in mind. Taken alone, I might have thought I knew what Russians and Ukrainians had in mind. But the U.S. answers confound me, and alongside these, I don't know what to think about the Russian and Ukrainian responses, either.

Question H4 poses the kind of question that invites my skepticism. Respondents are asked to imagine that they are suddenly ill and will feel tired all their lives unless they undergo a surgical operation that entails one chance in four of death. The survey asked, "Would you decide to undergo this operation?" I do not see how a person could give a serious answer to the question in the time that the interviewer waited for an answer, so I interpret the answers as not serious. Whether Americans who give answers that are not serious tend to give the same answers as Russians who give answers that are not serious I do not know, but it looks as though there is a remarkable similarity in the way Russians, Ukrainians, and Americans give snap answers to life-and-death questions.

I find the interpretations of some of the results unwarranted. An example is question C11. "Do you think that it is likely to be difficult to make friends with people who have their own business (individual or through a small corporation) and are trying to make a profit?" Twenty percent of New Yorkers, 51 percent of Russians, and 43 percent of Japa- 
nese answered yes. The authors refer to a yes answer as a "negative attitude toward business people." I do not see why that response is a negative attitude. Having spent almost forty years in an academic career and seven years in the federal government, I think on the basis of my experience I would have to answer yes-not because business people are unfriendly or because I couldn't be friends with somebody who was attracted to profit, but simply because my opportunities to meet people who have their own businesses in circumstances in which we might become friends are rare. A yes answer here may be a negative attitude toward one's own circumstances. If the question had been about friendliness and compatibility, it might have yielded a significant interpretation.

In the same way, I question the characterization of a negative answer to question $\mathrm{H} 1$ - unwillingness to work fourteen hours a day, six days a week, for the next five years in order to double one's level of well-being-as a lack of "ambition." At least I want to hear respondents' answers to the follow-up question, "Why are you unwilling?" If one is to be ambitious primarily for one's children, it isn't easy to know whether absenting oneself fourteen hours a day, six days a week for five years for the sake of a larger family income is the best or the worst thing one can do for one's children.

A conclusion I come to is that many of these survey responses are exceedingly difficult to interpret.

\section{General Discussion}

Several commentators suggested that persistent differences in experience are likely to lead to deep-seated differences in attitudes, thus blurring the distinction between situational and attitudinal influences. Janet Rothenberg Pack described the general issue as being how quickly behavior changes when the situation changes. She offered some conflicting observations from other episodes of social change. The literature in agricultural economics indicates that, as prices and markets have been freed, farmers have responded to economic incentives, regardless of their previous cultural and economic environment. By contrast, studies of the survivors of German concentration camps show that their subsequent behavior was permanently influenced by that experience. William Brainard observed that the Great Depression permanently affected the 
attitudes of a generation. Sidney Winter added that many people in the former Soviet Union were killed simply for being successful farmersthe "liquidation of the kulaks." He suggested that testing age-cohort effects and geographical differences could shed some light on whether these traumatic events continue to affect current attitudes.

Some panelists offered comments about how to interpret responses, particularly ones that seemed puzzling. Robert Hall noted that questions asking whether a certain event was possible would get some minimum positive response because some people believe "anything is possible." Alan Blinder suggested that a noticeable fraction of people will give crazy answers to any question, citing Patrick Buchanan's political support this spring as a current example. Cross-country comparisons could be affected if what passed for crazy answers differed in different countries. Similarly, gender and other demographic differences would be expected to affect answers systematically. However, Robert Shiller reported that the same percentage of telephone respondents in all countries were women-about 60 percent-so that gender should not bias comparisons. Thomas Schelling added that the habit of not answering questions truthfully or at all in a communist country might have influenced the reliability of the Soviet responses. Shiller reported his informal impression that people were most willing to cooperate with the survey in Russia and least cooperative in New York. On the other hand, Russians were more likely to reply "no answer" to some questions when being interviewed. He was not sure what to make of this.

William Nordhaus observed that questions could be interpreted differently by people from different regions-as opposed to being answered differently, given a common interpretation. He suggested having social scientists from the different regions explain what they thought the questions meant in order to see if they all interpreted them in the same way. Benjamin Friedman noted that, for some events, many more people contemplate an action than ever take it: he offered the known evidence on suicides as an example. He suggested that this phenomenon might help explain some questionnaire responses that appeared to be far out of line with observed behavior.

Holger Wolf suggested that the striking similarity between eastern and western German responses may be due to the influence of western German television, which had been accessible to the eastern Germans for 40 years. This might also help explain differences within the FSU be- 
tween areas that could receive Western TV and areas that could not. In his own travels, he had found that Tallin, an Estonian city that had received Finnish television for many years, had the feeling of a market economy, in contrast with the Ukrainian city of Kiev, which had been isolated from Western television. He suggested testing the influence of television by seeing if survey responses differed significantly between parts of eastern Germany that could not receive western German TV and the rest of eastern Germany. 


\section{References}

Akerlof, George A., and others. 1991. "East Germany in from the Cold: The Economic Aftermath of Currency Union." BPEA, 1:1991, 1-87.

Alexander, Lewis. 1991. "Radical Economic Reform in Germany, 1948 and 1990: Similarities, Differences, and Lessons for the Soviet Union." Unpublished paper, Board of Governors of the Federal Reserve System (June).

Andrews, John D. W. 1967. "The Achievement Motive and Advancement in Two Types of Organizations." Journal of Personality and Social Psychology 6: 163-68.

Blanchflower, David G., and Andrew J. Oswald. 1989. "International Patterns of Work." In British Social Attitudes: Special International Report. Aldershot: Gower.

Cochrane, John H., and Barry W. Ickes. 1991. "Inflationary Stabilization in Reforming Socialist Economies: The Myth of the Monetary Overhang." Comparative Economic Studies 33 (2): 97-122.

DiFranceisco, Wayne, and Zvi Gitelman. 1984. "Soviet Political Culture and 'Covert Participation' in Policy Implementation." American Political Science Review 78: 603-21.

Eisenstadt, S. N. 1963. "The Need for Achievement." Economic Development and Cultural Change 11: 420-31.

Gaenslen, Fritz. 1986. "Culture and Decision Making in China, Japan, Russia, and the United States." World Politics 39: 78-103.

Hofstede, Geert. 1980. Culture's Consequences: International Differences in Work-Related Values. Beverly Hills: Sage Publications.

Hoselitz, Bert F. 1952. "Non-Economic Barriers to Economic Development." Economic Development and Cultural Change 1: 8-21.

Juster, F. Thomas, and Frank P. Stafford. 1991. "The Allocation of Time: Empirical Findings, Behavioral Models, and Problems of Measurement." Journal of Economic Literature 29: 471-522.

Kahn, Shulamit, and Kevin Lang. 1989. "The Effects of Hours Constraints on Labor Supply Estimates." Unpublished paper, Boston University.

McClelland, David C. 1961. The Achieving Society. Princeton: D. Van Nostrand.

McClelland, David C., and David G. Winter. 1969. Motivating Economic Achievement. New York: Free Press.

Miron, David, and David C. McClelland. 1979. “The Impact of Achievement Motivation Training on Small Businesses." California Management Review 21(4): 13-28.

Sah, Raaj K. 1991. "Social Osmosis and Patterns of Crime." Journal of Political Economy 99: 1272-95. 
Shiller, Robert J., Maxim Boycko, and Vladimir Korobov. 1991. "Popular Attitudes toward Free Markets: The Soviet Union and the United States Compared." American Economic Review 81: 385-400.

Triandis, Harry C. 1972. The Analysis of Subjective Culture. New York: WileyInterscience.

- 1989. "Cross-Cultural Studies of Individualism and Collectivism." In Nebraska Symposium on Motivation, 1989, edited by John J. Berman. Lincoln, Neb.: University of Nebraska Press.

United States General Accounting Office. 1991. Soviet Economy: Assessment of How Well the CIA Has Estimated the Size of the Economy. GAO/NSIAD 91-274. Washington: General Accounting Office.

Weber, Max. 1920. General Economic History, translated by Frank H. Knight. New York: Collier Books, 1961.

Werner, Oswald, and Donald T. Campbell. 1970. "Translating, Working through Interpreters, and the Problem of Decentering." In A Handbook of Method in Cultural Anthropology, edited by Raoul Naroll and Ronald Cohen. New York: American Museum of Natural History. 